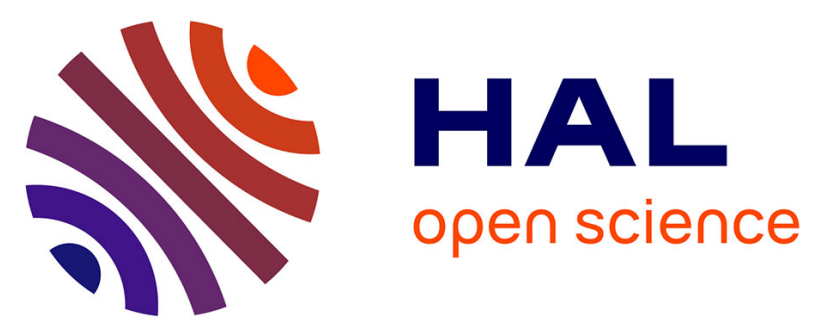

\title{
An annual survey of bacterial production, respiration and ectoenzyme activity in coastal NW Mediterranean waters: temperature and resource controls
}

B. Céa, Dominique Lefèvre, L. Chirurgien, Patrick Raimbault, N. Garcia, B. Charrière, Gérald Grégori, J. F. Ghiglione, A. Barani, M. Lafont, et al.

\section{To cite this version:}

B. Céa, Dominique Lefèvre, L. Chirurgien, Patrick Raimbault, N. Garcia, et al.. An annual survey of bacterial production, respiration and ectoenzyme activity in coastal NW Mediterranean waters: temperature and resource controls. Environmental Science and Pollution Research, 2015, 22 (18), pp.13654-13668. 10.1007/s11356-014-3500-9 . hal-01199850

\section{HAL Id: hal-01199850 \\ https://hal-univ-perp.archives-ouvertes.fr/hal-01199850}

Submitted on 18 Feb 2021

HAL is a multi-disciplinary open access archive for the deposit and dissemination of scientific research documents, whether they are published or not. The documents may come from teaching and research institutions in France or abroad, or from public or private research centers.
L'archive ouverte pluridisciplinaire HAL, est destinée au dépôt et à la diffusion de documents scientifiques de niveau recherche, publiés ou non, émanant des établissements d'enseignement et de recherche français ou étrangers, des laboratoires publics ou privés. 


\title{
An annual survey of bacterial production, respiration and ectoenzyme activity in coastal NW Mediterranean waters: temperature and resource controls
}

\author{
B. Céa - D. Lefèvre $\cdot$ L. Chirurgien $\cdot$ P. Raimbault $\cdot$ \\ N. Garcia • B. Charrière • G. Grégori • J. F. Ghiglione • \\ A. Barani • M. Lafont • F. Van Wambeke
}

\begin{abstract}
We simultaneously measured bacterial production (BP), bacterial respiration (BR), alkaline phosphatase activity (phos) and ectoaminopeptidase activity (prot) in relation to biogeochemical parameters, nutritive resources and in situ temperature over a 1-year survey at the long-term observatory the SOLEMIO station (Marseille bay, NW Mediterranean Sea). Despite its proximity to the coast, oligotrophic conditions prevailed at this station (yearly mean of $\mathrm{Chl} a=$ $0.43 \mu \mathrm{g} \mathrm{dm}^{-3}, \mathrm{NO}_{3}=0.55 \mu \mathrm{mol} \mathrm{dm}{ }^{-3}$ and $\mathrm{PO}_{4}=$ $0.04 \mu \mathrm{mol} \mathrm{dm}^{-3}$ ). Episodic meteorological events (dominant winds, inputs from the Rhone River) induced rapid oscillations (within 15 days) in temperature and sometimes salinity that resulted in rapid changes in phytoplankton succession and a high variability in $\mathrm{C} / \mathrm{P}$ ratios within the particulate and dissolved organic matter. Throughout the year, BP ranged from 0.01 to $0.82 \mu \mathrm{g} \mathrm{C} \mathrm{dm}-{ }^{3} \mathrm{~h}^{1}$ and bacterial growth efficiency varied from 1 to $39 \%$, with higher values in summer.
\end{abstract}

B. Céa $(\triangle) \cdot$ D. Lefèvre $\cdot$ L. Chirurgien $\cdot$ P. Raimbault $\cdot$ N. Garcia $\cdot$ B. Charrière $\cdot$ G. Grégori $\cdot$ A. Barani $\cdot \mathrm{M}$. Lafont $\cdot$ F. Van Wambeke Mediterranean Institute of Oceanography (MIO) UMR 7294, Aix-Marseille Université, Université de Toulon, IRD, CNRS, Marseille, France

e-mail: benj.cea@gmail.com

B. Charrière $\cdot$ G. Grégori

Centre de Formation et de Recherche sur les Environnements

Méditerranéens, University Perpignan Via Domitia, UMR5110,

Perpignan, France

G. Grégori · J. F. Ghiglione

Laboratoire d'Océanographie Biologique de Banyuls, CNRS, UMR

7621, Banyuls-sur-Mer, France

G. Grégori · J. F. Ghiglione

Laboratoire d'Océanographie Microbienne, Observatoire

Océanologique, Sorbonne Universités, UPMC Université Paris 06,

UMR 7621, Banyuls-sur-Mer, France
Enrichment experiments showed that BP was limited most of the year by phosphorus availability (except in winter). A significant positive correlation was found between in situ temperature, BP, BR and phos. Finally, we found that temperature and phosphate availability were the main factors driving heterotrophic bacterial activity and thus play a fundamental role in carbon fluxes within the marine ecosystem.

Keywords Bacterial production · Bacterial respiration . Bacterial growth efficiency $\cdot$ Ectoenzymes $\cdot$ Phosphorus limitation $\cdot$ SOLEMIO $\cdot$ NW Mediterranean Sea

\section{Introduction}

The dissolved organic carbon (DOC) pool is recycled into new biomass via heterotrophic bacterial production, BP which represents an entry for particulate organic carbon (POC) into the aquatic food web and $\mathrm{CO}_{2}$ metabolic production through remineralisation, i.e. bacterial respiration (BR). The magnitude of DOC flow through the heterotrophic bacterioplankton remains largely unknown because measurements of BP are seldom accompanied by BR measurements (Jahnke and Craven 1995). The bacterial growth efficiency (BGE) relates to the efficiency of the conversion, from dissolved to particulate organic carbon, according to the equation: $\mathrm{BGE}=\mathrm{BP} /$ $(\mathrm{BP}+\mathrm{BR})$. While BGE characterises the dynamics of heterotrophic bacteria, its estimation has a large degree of uncertainty (Jahnke and Craven 1995). Cole and Pace (1995) proposed that the high BGE variability may not be random but related to environmental constraints such as nutrient availability or organic substrate quality. Moreover, a consistent increase in BGE was found along gradients of productivity in aquatic systems, suggesting that BGE may be controlled by resources 
(Del Giorgio and Cole 1998). Other authors discussed the potential effects of temperature on BGE (Rivkin and Legendre 2001; Apple et al. 2006; López-Urrutia and Morán 2007; Kritzberg et al. 2010b; Berggren et al. 2010), but the relative importance of temperature and resources have not been explored.

Overall, bacterial processes are influenced by the quantity and quality of the organic substrate, as well as the availability of inorganic nutrients. For example, some substrates require enzymatic hydrolysis before uptake (Middelboe and Søndergaard 1993), and different organic molecules exhibit different energy to $\mathrm{C}$ ratios, which limits their utilisation by bacteria and therefore influence the bacterial growth efficiency (Vallino et al. 1996). According to the ecological Redfield stoichiometric theory, it has been shown that BGE decreases with increasing $\mathrm{C} / \mathrm{N}$ and $\mathrm{C} / \mathrm{P}$ ratios of the natural organic substrates (Kroer 1993; Vallino et al. 1996). Under such conditions, addition of inorganic nutrients stimulated the organic matter uptake by bacteria and the BGE (Kroer 1993; Kragh et al. 2008). As a consequence, heterotrophic bacteria living in oligotrophic oceans could compete with phytoplankton for mineral nutrients, such as $\mathrm{N}$ in the South Pacific (Torréton et al. 2000; Van Wambeke et al. 2008) and P in the Sargasso Sea (Cotner et al. 1997; Sebastian and Ammerman 2009). In the Mediterranean Sea, which is one of the most oligotrophic areas of the world's ocean, inorganic phosphorus has been shown to limit both phytoplankton and heterotrophic bacteria growth in certain areas (Krom et al. 1991; Zweifel et al. 1993; Thingstad et al. 1998; Christakill et al. 1999; Pinhassi et al. 2006) and over large longitudinal gradients (Van Wambeke et al. 2002).

In the NW Mediterranean Sea, a network of long-term observatory stations have been developed incorporating different habitats where the seasonal changes of BP in relation to physical and biogeochemical parameters have been investigated from one to several years (Pinhassi et al. 2006; AlonsoSáez and Gasol 2007; Alonso-Saez et al. 2008; Lami et al. 2009). Seasonal changes in BGE and ectoenzymatic activities have been less frequently investigated (Del Negro et al. 2008; Alonso-Saez et al. 2008). Here we investigated the seasonal variation of several components of the carbon flux mediated by heterotrophic bacteria in relation to biogeochemical changes at the long-term observatory SOLEMIO station (Marseille bay, NW Mediterranean Sea) by sampling surface seawater every 15 days over a year. Information on the substrate quantity and quality was provided by the biochemical composition of the organic pools (particulate and dissolved C, N, P stocks). We simultaneously measured BP, BR, alkaline phosphatase activity (phos) and ectoaminopeptidase activity (prot). We evaluated the influence of phosphorus $(\mathrm{P})$, nitrate $(\mathrm{N})$ and carbon (C) on BP in bioassay incubations.
The hydrodynamics of the Marseille Bay is complex and controlled by:

1. Two dominant winds: north-northwesterly (The Mistral), which favours upwelling from the "Cote Bleue" to the "Calanques," and south-easterly winds, which favour downwelling. Minas (1968) showed that primary production tripled at a coastal station influenced by upwelling compared with a reference offshore station.

2. The oligotrophic North Mediterranean Current (NMC), which flows along the continental slope towards the west (Millot 1990) can occasionally intrude on the shelf (Millot and Wald 1980; Gatti 2008).

The Rhône River mouth is situated 40 km westward from the Marseille Bay. According to observations (Broche et al. 1998) and modelling studies (Estournel et al. 2001; Reffray et al. 2004; Fraysse et al. 2013), the Rhône river plume exhibits most of the time a predominant westwards direction and, under those conditions, does not impact the Marseille Bay. However, a less common orientation toward the east has also been observed (Gatti et al. 2006; Fraysse et al. under review). The eastward extent is explained by different factors not necessarily related solely to the eastern winds, and including: Rhône river discharge volume, wind shifts and forcings, presence of a mesoscale eddy in the area, and variation in the thermocline depth (Fraysse et al., under review). An inventory of Rhône River intrusion events into the Bay of Marseille during the years 2007 to 2011 show an average of only 7.6 intrusions per year with a variable duration from 3 to 10 days (Fraysse et al. 2014).

\section{Materials and methods}

Study area and sample collection A time series study was established from January 2012 to February 2013, sampling sea water from the SOLEMIO station located in the Marseille bay (N 43 ${ }^{\circ} 14^{\prime} 30^{\prime \prime}$ and $\mathrm{E} 05^{\circ} 17^{\prime} 30^{\prime \prime}, 60 \mathrm{~m}$ depth) (Fig. 1), NW Mediterranean Sea. This station belongs to the SOMLIT network (http://somlit.epoc.u-bordeaux1.fr/fr/) which records a time series of several environmental parameters throughout the seasons from March 1994. Sampling was performed bimonthly aboard the R.V. Antedon II using a $20 \mathrm{dm}^{3}$ Niskin bottle coupled to a Seabird CTD system (SBE 19) for pressure, temperature, conductivity (salinity), fluorescence (chlorophyll $a$ ) and dissolved oxygen measurements. Our data set is limited to sampling at the surface $(1 \mathrm{~m}<\mathrm{S}<5 \mathrm{~m})$. Sea water was collected into $2 \mathrm{dm}^{3}$ polycarbonate bottles, stored in the dark in a portable incubator and set at in situ surface temperature. In the laboratory, samples were processed no more than $2 \mathrm{~h}$ after sampling. 
Fig. 1 Study site (SOLEMIO) location in the Marseille Bay, France, NW Mediterranean Sea. NMC: North Mediterranean Current

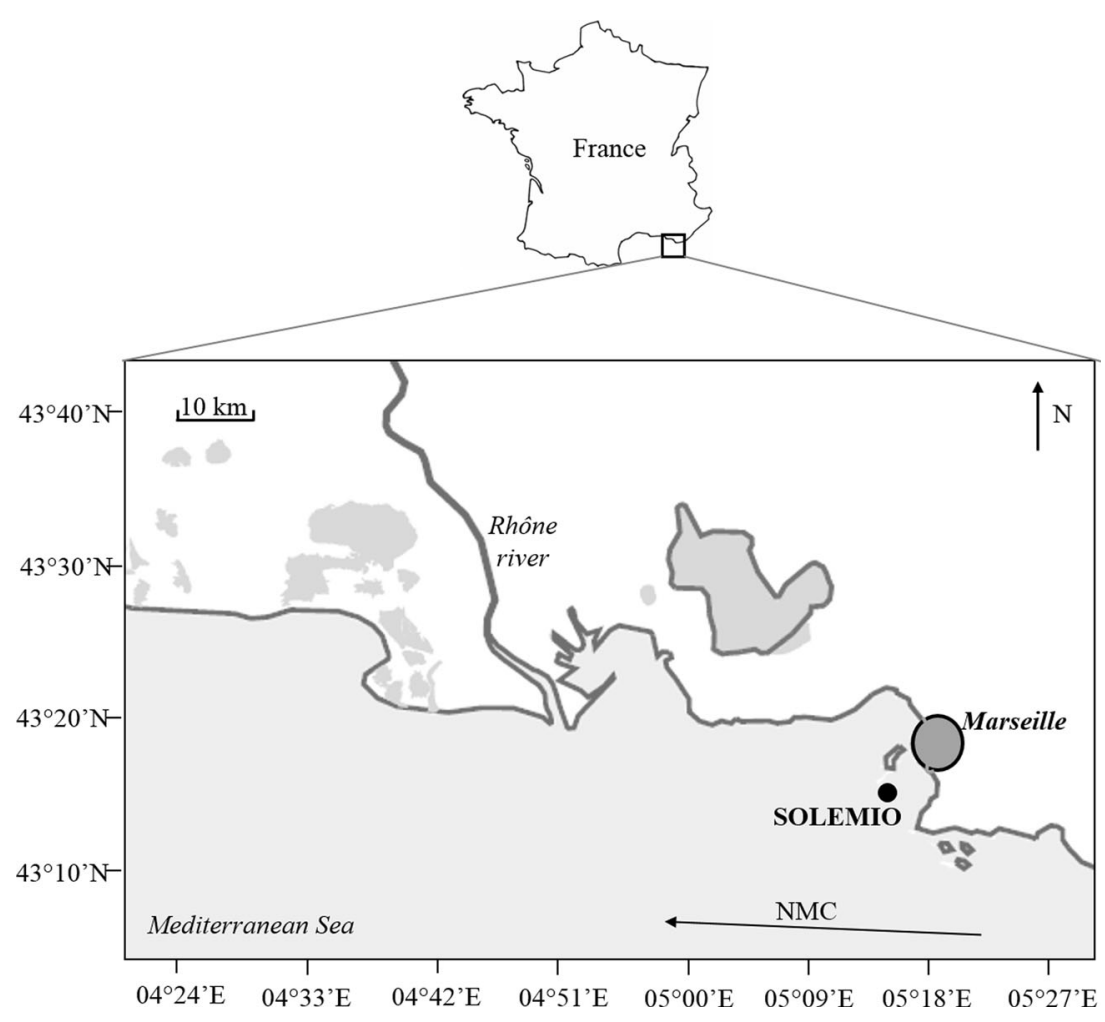

Chemical analysis A major advantage of sampling at the SOLEMIO station, from the SOMLIT network, is that biogeochemical variables have been measured and recorded since January 2000. Thus, we had access to historical data temperature, salinity, chlorophyll $a$ concentration ( $\mathrm{Chl} a$ ), nitrate, phosphorus, orthosilicic acid $\left(\mathrm{NO}_{3}, \mathrm{PO}_{4}, \mathrm{SiOH}_{4}\right.$, respectively), particulate organic carbon and nitrogen (POC and PON). During our study, other environmental variables (total nitrogen, total phosphorus, particulate phosphorus) were performed. Chl a concentrations were determined by spectrofluorimetry (limit of detection of $0.05 \mu \mathrm{g} \mathrm{dm}{ }^{-3}$ and, reproducibility of $5 \%$ ) following the method of Raimbault et al. (2004). $\mathrm{NO}_{3}, \mathrm{PO}_{4}, \mathrm{SiOH}_{4}, \mathrm{TON}$ and TOP concentrations were measured by a Technicon AutoAnalyzer ${ }^{\circledR}$ (limit of detection of $0.5,0.020,0.1,0.1,0.03 \mu \mathrm{mol} \mathrm{dm}{ }^{-3}$, respectively with a reproductibility of $5 \%$ ) following the method of Tréguer and Le Corre (1975) and Raimbault et al. (1990). POC and PON concentrations were determined by combustion of particulate matter recovered after filtration (GF/F Whatman ${ }^{\circledR}$ filter $\left.25 \mathrm{~mm}\right)$. The combustion of organic matter product $\mathrm{CO}_{2}, \mathrm{CO}$ (if combustion is incomplete) and $\mathrm{NO}_{\mathrm{x}}$ which are converted in $\mathrm{CO}_{2}$ and $\mathrm{N}_{2}$ then separate by gas chromatography and quantified by TCD (Thermal Conductivity Detector) detector type (limit of detection of 10 and $5 \mu \mathrm{g} \mathrm{dm}^{-3}$, respectively and, reproducibility of $10 \%$ ) follows the method of Aminot and Kérouel (2004). DON and DOP concentrations were derived from TON minus
$\left(\mathrm{PON}+\mathrm{NO}_{3}+\mathrm{NO}_{2}+\mathrm{NH}_{4}\right)$ concentrations, and from TOP minus $\left(\mathrm{POP}+\mathrm{PO}_{4}\right)$ concentrations, respectively. Samples for POP analysis were determined by Chemical wet-oxidation (limit of detection of $0.005 \mu \mathrm{mol} \mathrm{dm}{ }^{-3}$ with a reproducibility of $10 \%$ ) following the method of Raimbault et al. (1999). For this method, $250 \mathrm{~cm}^{3}$ of sea water was filtered from each depth through glass microfiber filters. TOC samples were collected in pre-combusted $\left(450{ }^{\circ} \mathrm{C}\right.$ for 4 to $\left.5 \mathrm{~h}\right)$ glass ampoules, immediately acidified with a drop of $1 \mu \mathrm{mol} \mathrm{dm} \mathrm{dm}^{-3}$ orthophosphoric acid, flame-busted and stored at $-4{ }^{\circ} \mathrm{C}$ until analysis. TOC analysis were performed using high temperature combustion on a Shimadzu ${ }^{\circledR}$ TOC-5000 total organic carbon analyzer (limit of detection of $0.1 \mu \mathrm{mol} \mathrm{dm}{ }^{-3}$ and reproducibility of $2 \%$ ) following the method of Cauwet 1994. All DOC concentrations reported were derived from the difference between TOC and POC concentrations from each sample.

Prokaryote and phytoplankton counting Flow cytometry analyses were carried out at the PRECYM flow cytometry platform (https://precym.mio.univ-amu.fr/). Samples were analysed using a FACSCalibur (BD Biosciences ${ }^{\circledR}$ San Jose, CA). For heterotrophic bacterial abundance (BA), $1.8 \mathrm{~cm}^{3}$ of sea water was fixed with formaldehyde (2\% final concentration, 15 min incubation at RT) frozen and stored in liquid nitrogen until analysis in the laboratory. After rapid thawing, samples were incubated with SYBR Green II 
(SIGMA, final conc. $0.05 \%[v / v]$ of the commercial solution, for $15 \mathrm{~min}$, at $20^{\circ} \mathrm{C}$ in the dark) in order to stain the nucleic acid and analysed according to Marie et al. (1997). Prochlorococcus were excluded from the counts, thanks to their red fluorescence which is induced by photosynthetic pigments.

Some of the phytoplankton, the ultraphytoplankton (Synechococcus, Prochloroccocus, picophytoeukaryotes and nanophytoeukaryotes) were analysed using flow cytometry to determine abundance. The $4.5 \mathrm{~cm}^{3}$ of seawater was collected, and samples were processed as for bacterial samples (fixation with formaldehyde, freezing and storage in liquid nitrogen). In the present study, the red fluorescence of the cells $(>650 \mathrm{~nm}$, ChloroA) related to the chlorophyll $a$ content of phytoplankton cells. These cells were also characterised by three other optical signals: forward scatter (FSC) related to cell size, side scatter (SSC) related to cell structure and orange fluorescence (564-606 nm-PE) related to phycoerythrin using the techniques found in Grégori et al. (2001).

All data were collected using the CellQuest software (BD Biosciences ${ }^{\circledR}$ ), and the analysis of the bacteria and the ultraphytoplankton groups were performed using SUMMIT v4.3 software (Beckman Coulter ${ }^{\circledR}$ ). TruCount beads (BD Biosciences ${ }^{\circledR}$ ) were added to the samples to accurately determine the volume analysed. Polystyrene beads $(2 \mu \mathrm{m}$ in diameter) were used as an internal standard and to discriminate between picoplankton $(<2 \mu \mathrm{m})$ and nanoplankton $(>2 \mu \mathrm{m})$ populations (Fluoresbrite YG, Polyscience). Diatom quantification was carried out by microscopy using the Lugol-fixed samples. Identification and counting of nano- and microplankton was carried out by direct observation using an inverted microscope according to Utermöhl method.

$B P, C R, B R$ and $B G E$ Bacterial production (BP) was estimated using the ${ }^{3} \mathrm{H}$-leucine (Leu) incorporation technique (Kirchman et al. 1985), adapted to the centrifugation method (Smith and Azam 1992). For each sample, triplicate aliquots $\left(1.5 \mathrm{~cm}^{3}\right)$ and one trichloroacetic acid (TCA) killed control were incubated with a mix of $6 \mathrm{nmol} \mathrm{dm}{ }^{-3}$ hot leucine $\left(\mathrm{L}-\left[{ }^{3} \mathrm{H}\right]\right.$ leucine, Perkin Elmer ${ }^{\circledR}$ specific activity ranging $107-$ $144 \mathrm{Ci} \mathrm{mmol}^{-1}$ ) and $14 \mathrm{nmol} \mathrm{dm}^{-3}$ cold leucine in the dark, at in situ temperature, for $2 \mathrm{~h}$. Preliminary experiments confirmed that leucine incorporation was linear during this period. The live incubations were terminated with $5 \%$ TCA (final concentration). After three runs of centrifugation/aspiration of the supernatant (once with the fixed sea water sample, once with a $5 \%$ TCA rinse, once with an $80 \%$ ethanol rinse), the pellet was resuspended in Packard Ultima Gold MW Scintillation liquid $^{\circledR}$. Radioactivity was counted using a Liquid Scintillation Analyzer Packard ${ }^{\circledR} 2100$ TR, and the $3 \mathrm{H}$ counting efficiency was corrected for quenching. Concentration kinetic experiments showed that isotopic dilution was negligible when using $20 \mathrm{nmol} \mathrm{dm}^{-3}$ leucine, and thus, BP rates were calculated from leucine incorporation rates using the conversion factor of $1.5 \mathrm{~kg} \mathrm{C} \mathrm{mol}^{-1}$ leucine and given in micrograms carbon per cubic decimeters per hour. Daily rates were calculated assuming they are 24 times the hourly rate.

Community respiration (CR) was determined from nonfiltered sea water using the Winkler method and given in micrograms carbon per cubic decimeters per hour. Four replicate $125 \mathrm{~cm}^{3}$ borosilicate glass bottles were carefully filled, and four other replicates were immediately fixed with Winkler reagents to determine the initial oxygen concentration. The replicate bottles were incubated in the dark, at in situ temperature, and fixed with Winkler reagents after $24 \mathrm{~h}$. Dissolved oxygen measurements were made using an automatic colorimetric endpoint detector (Williams and Jenkinson 1982). The respiration rate was determined by dividing the oxygen concentration difference (initial-final) by the incubation time, assuming a linear consumption of oxygen with time. In order to determine the bacterial respiration rate (BR), incubations were performed on filtrate that had passed through a $0.6 \mu \mathrm{m}$ polycarbonate filter. BR was on average $90 \%$ of CR $(n=4)$, which is a mean value of $67 \pm 9 \%$ greater than previously observed in the open NW Mediterranean Sea (Lemée et al. 2002). The fraction of $C R$ attributed to $B R$ could be overestimated with the classical method of filtration. Aranguren-Gassis et al. (2012) found the following relationship: $\mathrm{BR}=0.3 \times \mathrm{CR}$ from in vivo ETS experiments in two contrasting environments: the highly productive Ría de Vigo (NW Spain) and the North Atlantic oligotrophic gyre. This fraction can also vary during incubation with some changes in the bacterial community composition (Massana et al. 2001). Applying a constant BR fraction from $30 \%$ to $100 \%$, the absolute BGE values would vary, but the seasonal trend of BGE would not change. Having no systematic seasonal estimates of BR, we kept 0.9 to calculate the BR fraction for the whole period of this study. We assumed a respiratory quotient of 0.8 (del Giorgio and Williams 2005). Thereby, owing to the difficulty of estimating the $\mathrm{BR}$ fraction within $\mathrm{CR}$, BGE was calculated as $\mathrm{BGE}=\mathrm{BP} /(\mathrm{BP}+0.9 \times \mathrm{CR})$ with $\mathrm{BP}$ and $\mathrm{BR}$ expressed in micrograms carbon per cubic decimeters per hour and where $\mathrm{CR}$ was calculated from the incubations described above and BP was determined using the incorporation of leucine in non-filtered sea water at each depth at the sampling time. Due to technical problems, accurate measurements of respiration rates started only in March 2012.

Ectoenzymatic activity Alkaline phosphatase activity (phos) was measured fluorometrically using methylumbelliferone phosphate (MUF-P) following the method of Hoppe 1983. The $30 \mathrm{~mm}^{3}$ of a $0.1 \mathrm{mmol} \mathrm{dm}{ }^{-3}$ MUF-P solution was added to $3 \mathrm{~cm}^{3}$ of seawater sample and then aliquoted into a $1-\mathrm{cm}$ PMMA cuvette for measurement. Stock solutions of $5 \mathrm{mmol} \mathrm{dm}{ }^{-3}$ MUF-P in methylcellosolve were stored at 
$-20{ }^{\circ} \mathrm{C}$ and diluted with boiled filtered sea water prior to use. The linear increase in fluorescence in the sea water samples with added MUF-P was measured over the incubation time (from 2 to $5 \mathrm{~h}$ ), in the dark at in situ temperature (excitation at $365 \mathrm{~nm}$ and emission at $460 \mathrm{~nm}$ ), using a Kontron ${ }^{\circledR}$ SFM 23B spectrofluorometer. Calibration curves were made using MUF standards diluted in boiled seawater. The kinetic coefficients were determined on surface sea water samples using a range of concentrations of MUF-P from 25 to $1,000 \mathrm{nmol} \mathrm{dm}^{-3}$. The Michaelis-Menten equation was used to determine kinetic coefficients: $V=(V m \times S) /(K m+S)$, where $S$ is the MUF-P concentration and $V$ the hydrolysis rate. $V m$ (nanomoles per cubic decimeters per hour) and $K m$ (nanomoles per cubic decimeters) have been specified from a non-linear regression calculated with the PRISM software. Then, the $\mathrm{Km} / \mathrm{Vm}$ ratio enabled the estimation of the Turnover time (hours) of the enzymatic reaction. Blanks were run by adding the MUF-P to filtered boiled sea water and were shown to be insignificant.

Protease activity (prot) was determined by measuring the hydrolysis rate of L-leucine-4-methyl-7-coumarinylamide (leu-MCA, Sigma), which is used as an analogue substrate for natural peptides (Hoppe 1983). Stock solutions of $10 \mathrm{mmol} \mathrm{dm}^{-3}$ leu-MCA were prepared in methylcellosolve and kept at $-20{ }^{\circ} \mathrm{C}$. As for phos, concentration kinetics were undertaken for sea surface layers, but using a range of concentrations of leu-MCA from 0.5 to $400 \mu \mathrm{mol} \mathrm{dm}{ }^{-3}$ and setting the excitation to $380 \mathrm{~nm}$ and the emission to $440 \mathrm{~nm}$. Samples for prot were incubated, in the dark, at in situ temperature during the analysis time. Phos and prot were determined from non-filtered sea water, and only $V m$ was conserved in the time series with their corresponding $\mathrm{Km}$.

Enrichment experiments The availability of phosphorus (P), nitrate $(\mathrm{N})$ and carbon $(\mathrm{C})$ in the sea water column was investigated by measuring changes in bacterial production following additions of $\mathrm{PO}_{4}\left(0.25 \mu \mathrm{mol} \mathrm{dm}{ }^{-3} \mathrm{P}\right), \mathrm{NO}_{3}$ and $\mathrm{NH}_{4}\left(1 \mu \mathrm{mol} \mathrm{dm}{ }^{-3}\right.$ each) or glucose $\left(10 \mu \mathrm{mol} \mathrm{dm}{ }^{-3} \mathrm{C}\right)$ (final concentrations). Several bioassays were realised: P, N, C, PN, $\mathrm{PC}, \mathrm{NC}$ and PNC including the non-enriched control (T). Each bioassay condition was made in triplicate in $60 \mathrm{~cm}^{3}$ polycarbonate bottles incubated at in situ temperature, in the dark over $48 \mathrm{~h}$. Following incubation, each bottle was subsampled in order to measure BP. BP subsamples were determined with the leucine technique described above using the same temperature conditions as for the bioassays (in the dark, for $2 \mathrm{~h}$ ).

Statistical analysis Our observations were log-transformed to stabilise the heterogeneity of variance before computing statistics. We used a $t$ test for listing significant differences $(p<0.05)$ between different combinations of enrichment experiments. From matrices of linear correlation, we examined partial correlation coefficients $(r)$ between the heterotrophic bacterial rates (BP, BR, phos and prot), in situ temperature and $\mathrm{Chl} a$. As the number of observations differs for each variable, we carried out the analysis on a set of three or four variables at a time, based on the common number of observations. The significance of $r$ was considered for $p=0.05, p=0.01$ and $p=$ 0.001 according to the degree of freedom $(d f=n-k-2$ with $k=$ number of variables and $n=$ number of observation).

\section{Results}

Environmental factors The SOLEMIO station (depth $60 \mathrm{~m}$ ) is situated in the Gulf of Lion (North Western Mediterranean Sea) to the south of the Marseille Bay $6 \mathrm{~km}$ off the coast, next to the Frioul Island. The hydrodynamics are mostly governed by the winds, general circulation of the NMC, bathymetry and the Rhône river influence. The wind direction compass (Fig. 2) showed two major winds: north westerly or the mistral and south easterly winds. The water temperature at the seasurface varied between $12.8{ }^{\circ} \mathrm{C}$ in January and $25.8{ }^{\circ} \mathrm{C}$ in August (Table 1 and Fig. 3a) with a cooling event in July $\left(15.7^{\circ} \mathrm{C}\right)$ caused by the mistral. Salinity was homogeneous over the water column $(38.15 \pm 0.02)$ except during the summer stratified condition where one lower salinity event (offset with the cooling event) was recorded in July (37.5 in upper layers, Fig. 3b) which appeared to be induced by a freshwater Rhône intrusion towards the Marseille Bay (http://www. previmer.org). Indeed, salinity $<37.8$ is considered as a threshold for an intrusion of Rhône River waters into the bay of Marseille (Gatti et al. 2006; Pairaud et al. 2011).

Chl $a$ was generally low and varied between 0.2 and $0.5 \mu \mathrm{g} \mathrm{dm}^{-3}$ at the sea-surface, except in late February and March when values reached $1.43 \mu \mathrm{g} \mathrm{dm}^{-3}$ (Fig. 3c). Highest $\mathrm{SiOH}_{4}, \mathrm{NO}_{3}$ and $\mathrm{PO}_{4}$ concentrations (between $1.5 \mu \mathrm{mol} \mathrm{dm}{ }^{-3}$ and $2.09 \mu \mathrm{mol} \mathrm{dm}{ }^{-3}, 0.08 \mu \mathrm{mol} \mathrm{dm}{ }^{-3}$ and $0.10 \mu \mathrm{mol} \mathrm{dm}{ }^{-3}$ and $2 \mu \mathrm{mol} \mathrm{dm}{ }^{-3}$ and $3.57 \mu \mathrm{mol} \mathrm{dm}{ }^{-3}$, respectively) were observed (Fig. 4a, b and c) during the winter (January and February 2012, 2013) characterised by a homogeneous water column (data not shown), rich in nutrients $\left(\mathrm{NO}_{3}, \mathrm{PO}_{4}\right.$ and $\mathrm{SiOH}_{4}$ ) and under the effect of the mistral and a few strong southeasterly wind events. Inversely, when summer arrived, stratification of the water column occurred, with lower nutrient concentrations $\left(\mathrm{NO}_{3}, \mathrm{PO}_{4}\right.$ and $\left.\mathrm{SiOH}_{4}\right)$, with a period showing shifts between a calm and a few events period of low mistral and southeasterly winds. Summer is characterised by the lowest $\mathrm{NO}_{3}$ and $\mathrm{PO}_{4}$ concentrations (below $0.5 \mu \mathrm{mol} \mathrm{dm} \mathrm{dm}^{-3}$ and below detection limits of $0.03 \mu \mathrm{mol} \mathrm{dm}{ }^{-3}$, respectively). Despite a period of depletion, $\mathrm{SiOH}_{4}$ was always higher than $1 \mu \mathrm{mol} \mathrm{dm}{ }^{-3}$ in the deeper layers (data not show) and increased progressively and earlier (in October) than $\mathrm{NO}_{3}$ and $\mathrm{PO}_{4}$, this being visible particularly at the sea-surface. 
Fig 2 Wind direction compass from January 2012 to February 2013 at the SOLEMIO station

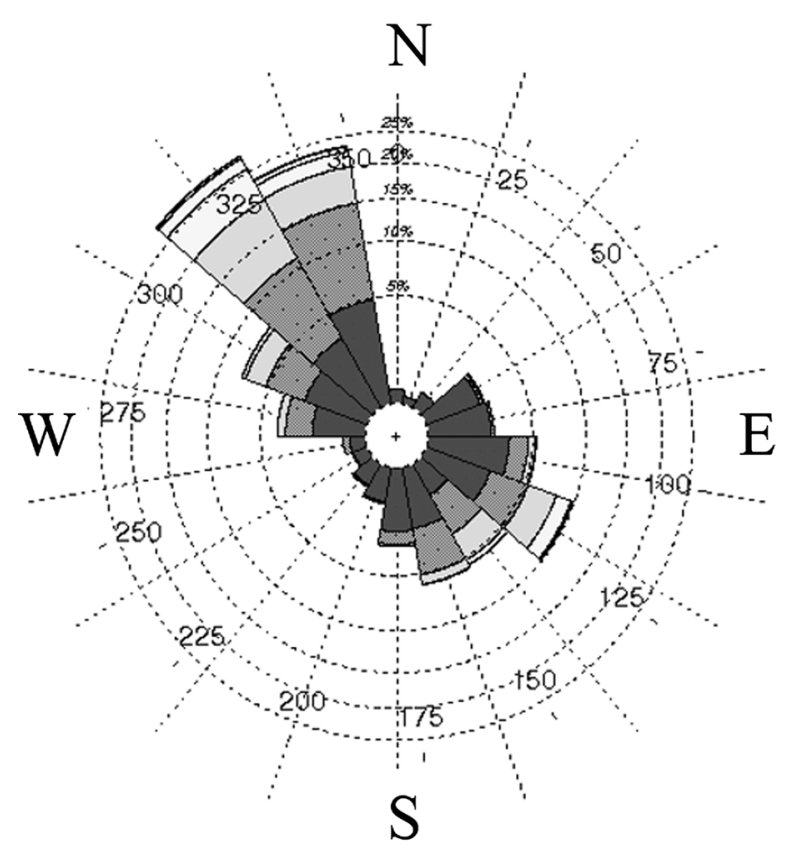

Organic matter $(C, N, P)$ Three peaks of DOC $\left(>130 \mu \mathrm{mol} \mathrm{dm}{ }^{-3}\right)$ were observed in January, March, August and November (Fig. 4d) whereas the lowest concentrations $\left(<50 \mu \mathrm{mol} \mathrm{dm}{ }^{-3}\right)$ were measured in March and April. DON increased from 4 to $11 \mu \mathrm{mol} \mathrm{dm}{ }^{-3}$ (Fig. 4e) during the survey with lowest values observed in January and February 2012 and highest values during the summer stratified conditions. DOP concentrations stayed low throughout the survey $\left(<0.6 \mu \mathrm{mol} \mathrm{dm}{ }^{-3}\right)$ and ranged from $0.08 \mu \mathrm{mol} \mathrm{dm}{ }^{-3}$ at the beginning of the cruise to $0.56 \mu \mathrm{mol} \mathrm{dm}{ }^{-3}$ at the end (Fig. $4 \mathrm{f}$ ). POC concentrations increased from the spring bloom period to reach its highest values in May, June and August and decreased from September down to $2 \mu \mathrm{mol} \mathrm{dm}{ }^{-3}$ in winter (Fig. $4 \mathrm{~g}$ ). From September to February 2013, the POC average concentration was $3.08 \mu \mathrm{mol} \mathrm{dm}{ }^{-3} \pm 0.17$. Similarly, PON concentrations began to increase from the spring bloom period and reached a maximum during the stratified period in August and decreased from September to homogenise around $0.51 \mu \mathrm{mol} \mathrm{dm}{ }^{-3} \pm 0.03$ during the winter mixed period (Fig. 4h). POC and PON showed their lowest values in July $\left(0.87\right.$ and $0.21 \mu \mathrm{mol} \mathrm{dm}{ }^{-3}$, respectively). There were three periods of high POP concentrations $\left(>0.05 \mu \mathrm{mol} \mathrm{dm}{ }^{-3}\right)$ : the spring bloom period (in March), the stratified period in summer (June, July and August) and the mixed period in winter (December, January and February 2013) (Fig. 4i). POC/PON ratios were stable, around 6.7 \pm 0.4 with a decrease at the end of the survey (about 4). POC/POP ratios ranged from 13 to 348 , and PON/POP ratios from 3 to 53 during the survey. For dissolved organic matter, the annual average DOC/DON ratio was $10 \pm 1$, that of $\mathrm{DOC} / \mathrm{DOP}$ ratio
$306 \pm 55$ and DON/DOP $31 \pm 4$. Annual variability of C/N, C/P and $\mathrm{N} / \mathrm{P}$ ratios for particulate organic matter were higher than those of dissolved organic matter (32\% versus $20 \%$, $64 \%$ versus $60 \%$ and $61 \%$ versus $51 \%$, respectively).

Cell abundance Cell abundance is characterized by a succession of phytoplanktonic and bacterioplanktonic populations. Indeed, the maximal abundance of diatoms occurred in March (Fig. 5a) with the beginning of the spring phytoplankton bloom (from February to May). Then, their abundance dropped rapidly and remained low for the rest of the survey $\left(<1,000\right.$ cell $\left.\mathrm{dm}^{-3}\right)$ except for two peaks in July and August. The abundance of picophytoplankton (cells $<2 \mu \mathrm{m}$ in size) increased during mixing (from December to February 2013) and during the spring phytoplankton bloom. The abundance of nanophytoeukaryotes was relatively stable, except for some small increases in April and August and from December to February 2013. The abundance of Synechococcus reached its maximum in April and May after the spring phytoplankton bloom, then in August during the stratification period (Fig. 5b). The abundance of Prochlorococcus was low during the spring phytoplankton bloom but increased from August to December. Heterotrophic bacteria (BA) were at a maximum (peaked) at the end of the spring phytoplankton bloom (late March and April) with some peaks in May and June, remaining stable during other periods (Fig. 5c). The first phase of this bloom was dominated by diatoms and picophytoplankton whose growth stopped following the depletion of $\mathrm{SiOH}_{4}$ in the water column. This is followed by a change in 
Table 1 Summary of the variables measured in sea-surface waters at the SOLEMIO station from January 2012 to February 2013 showing observation period, maximum value, minimum value, average and SE ${ }^{\text {a }}$ Values cited excluding three
outliers; see discussion

\begin{tabular}{|c|c|c|c|c|}
\hline Sea-surface variable & Period & Min & Max & Average $( \pm \mathrm{SE})$ \\
\hline \multicolumn{5}{|l|}{ Environmental factors } \\
\hline Temperature $\left({ }^{\circ} \mathrm{C}\right)$ & Jan 12-Feb 13 & 12.8 & 25.8 & $16.7( \pm 0.7)$ \\
\hline Salinity (psu) & Jan 12-Feb 13 & 37.53 & 38.37 & $38.15( \pm 0.03)$ \\
\hline Chl $a\left(\mu \mathrm{g} \mathrm{dm}^{-3}\right)$ & Jan 12-Feb 13 & 0.13 & 1.43 & $0.43( \pm 0.07)$ \\
\hline Nitrate $\left.(\mu \mathrm{mol} \mathrm{dm})^{-3}\right)$ & Jan 12-Feb 13 & 0.00 & 2.09 & $0.55( \pm 0.13)$ \\
\hline Phosphorus $\left.(\mu \mathrm{mol} \mathrm{dm})^{-3}\right)$ & Jan 12-Feb 13 & 0.00 & 0.10 & $0.04( \pm 0.01)$ \\
\hline Silicate $\left(\mu \mathrm{mol} \mathrm{dm}{ }^{-3}\right)$ & Jan 12-Feb 13 & 0.18 & 3.57 & $1.84( \pm 0.14)$ \\
\hline \multicolumn{5}{|l|}{ Organic matter $\left(\mu \mathrm{mol} \mathrm{dm}{ }^{-3}\right)$} \\
\hline $\mathrm{DOC}^{\mathrm{a}}$ & Jan 12-Feb 13 & 46 & 104 & $75( \pm 5)$ \\
\hline DON & Jan 12-Feb 13 & 4 & 11 & $7( \pm 1)$ \\
\hline DOP & Jan 12-Feb 13 & 0.08 & 0.56 & $0.31( \pm 0.04)$ \\
\hline POC & Jan 12-Feb 13 & 0.87 & 14.15 & $5.53( \pm 0.64)$ \\
\hline PON & Jan 12-Feb 13 & 0.21 & 3.10 & $0.88( \pm 0.12)$ \\
\hline POP & Jan 12-Feb 13 & 0.018 & 0.070 & $0.040( \pm 0.005)$ \\
\hline \multicolumn{5}{|l|}{ Cellular abundance } \\
\hline Heterotrophic bacteria $\left(\times 10^{5}\right.$ cell $\left.\mathrm{cm}^{-3}\right)$ & Jan 12-Feb 13 & 2.467 & 14.020 & $5.716( \pm 0.499)$ \\
\hline Synechococcus $\left(\times 10^{5}\right.$ cell $\left.\mathrm{cm}^{-3}\right)$ & Jan 12-Feb 13 & 0.046 & 1.357 & $0.416( \pm 0.091)$ \\
\hline Prochlorococcus $\left(\times 10^{5}\right.$ cell $\left.\mathrm{cm}^{-3}\right)$ & Jan 12-Feb 13 & 0.018 & 0.567 & $0.180( \pm 0.037)$ \\
\hline Picophytoplankton $\left(\times 10^{5}\right.$ cell $\left.\mathrm{cm}^{-3}\right)$ & Mar 12-Dec 12 & 0.003 & 0.163 & $0.051( \pm 0.010)$ \\
\hline Nanophytoeukaryotes $\left(\times 10^{5}\right.$ cell $\left.\mathrm{cm}^{-3}\right)$ & Jan 12-Feb 13 & 0.010 & 0.044 & $0.022( \pm 0.002)$ \\
\hline Diatoms $\left(\times 10^{5}\right.$ cell $\left.\mathrm{dm}^{-3}\right)$ & Mar 12-Dec 12 & 0.00 & 1.41 & $0.11( \pm 0.07)$ \\
\hline \multicolumn{5}{|l|}{ Heterotrophic bacterial activities } \\
\hline Bacterial production $\left(\mu \mathrm{g} \mathrm{C} \mathrm{dm}-{ }^{3} \mathrm{~h}^{1}{ }^{1}\right)$ & Jan 12-Feb 13 & 0.01 & 0.82 & $0.10( \pm 0.03)$ \\
\hline Community respiration $\left(\mu \mathrm{g} \mathrm{C} \mathrm{dm}-{ }^{3} h^{-1}\right)$ & Mar 12-Feb 13 & 0.11 & 2.32 & $0.59( \pm 0.13)$ \\
\hline Phos (Vm: $\left.\mathrm{nmol} \mathrm{dm}-{ }^{3} \mathrm{~h}^{-1}\right)$ & Jan 12-Feb 13 & 0.1 & 116.5 & $15.7( \pm 6.0)$ \\
\hline $\operatorname{Prot}\left(\operatorname{Vm}: \mathrm{nmol} \mathrm{dm}-{ }^{3} \mathrm{~h}^{-1}\right)$ & Mar 12-Feb 13 & 5.1 & 85.1 & $28.0( \pm 8.8)$ \\
\hline $\mathrm{BGE}(\%)=\mathrm{BP} /(\mathrm{BP}+0.9 \times \mathrm{CR}) \times 100$ & Mar 12-Feb 13 & 1 & 39 & $17( \pm 2)$ \\
\hline
\end{tabular}

phytoplankton dominance with the arrival of non-siliceous organisms the cyanobacteria (Synechoccocus and Prochloroccocus) and then an increase in heterotrophic bacteria. Thus, the transition period between mixed and stratified conditions is marked by a spring phytoplankton bloom characterised by maximum $\mathrm{Chl} a, \mathrm{NO}_{3}$ and $\mathrm{PO}_{4}$ concentrations together with high particulate organic matter concentrations $(\mathrm{C}, \mathrm{N}, \mathrm{P})$.

Heterotrophic bacterial activity and growth efficiency The highest BP values $\left(>0.2 \mu \mathrm{g} \mathrm{C} \mathrm{dm}{ }^{-3} \mathrm{~h}^{-1}\right)$ were observed during the summer (late May, June, July and August) with a smaller BP increase ( 0.05 to $\left.0.2 \mu \mathrm{g} \mathrm{C} \mathrm{dm}{ }^{-3} \mathrm{~h}^{-1}\right)$ during the spring bloom period ( in March and April) in the upper layers (Fig. 6a). Maximum CR values $\left(>1 \mu \mathrm{g} \mathrm{C} \mathrm{dm}{ }^{-3} \mathrm{~h}^{-1}\right.$ ) were observed during the summer period (from May to August) (Fig. 6b). During the remainder of the survey, CR varied from 0.2 to $0.8 \mu \mathrm{g} \mathrm{C} \mathrm{dm}{ }^{-3} \mathrm{~h}^{-1}$.

The lowest BGE (1\% to $10 \%$ ) were generally obtained in winter (from October 2012 to February 2013), whilst the highest BGE (20\% to $39 \%$ ) was found, during summer
(Fig. 6b). However, a low BGE (5\%) was found in August, during the temperature peak $\left(25.8^{\circ} \mathrm{C}\right)$ coinciding with a period of delayed increase in BP with regard to BR. During the spring bloom (March, April), BGE was around $15 \%$.

Maximum rates of phos occurred in the summer (Fig. 6a) especially within surface layers (late in May, June, July and early in August), during stratification where the water column was P-limited (Table 2). However, phos had already started to increase during the spring bloom period with values $>4 \mathrm{nmol} \mathrm{dm}^{-3} \mathrm{~h}^{-1}$. Like phos, prot reached its highest values in summer (July and August) (Table 2). Lower prot $\left(<20 \mathrm{nmol} \mathrm{dm}^{-3} \mathrm{~h}^{-1}\right)$ values were observed during the winter. Cell-specific MCA-Leu hydrolysis rates at the SOLEMIO station ranged between 15 and $131 \times 10^{-18}$ mol MCA-Leu cell $^{-1} \mathrm{~h}^{-1}$, and cell-specific MUF-P hydrolysis ranged from 0.3 and $163 \times 10^{-18}$ mol MUF-P cell ${ }^{-1} \mathrm{~h}^{-1}$.

The coefficients of partial correlation (Table 3 ) calculated from respective correlation matrices (data not shown) revealed that (1) only phos and BP showed a significant relationship independently to prot and BR $(r(\mathrm{BP}-p h o s)=0.91, d f=4$, $p<0.01)$, (2) BP, BR and phos were correlated with in situ 

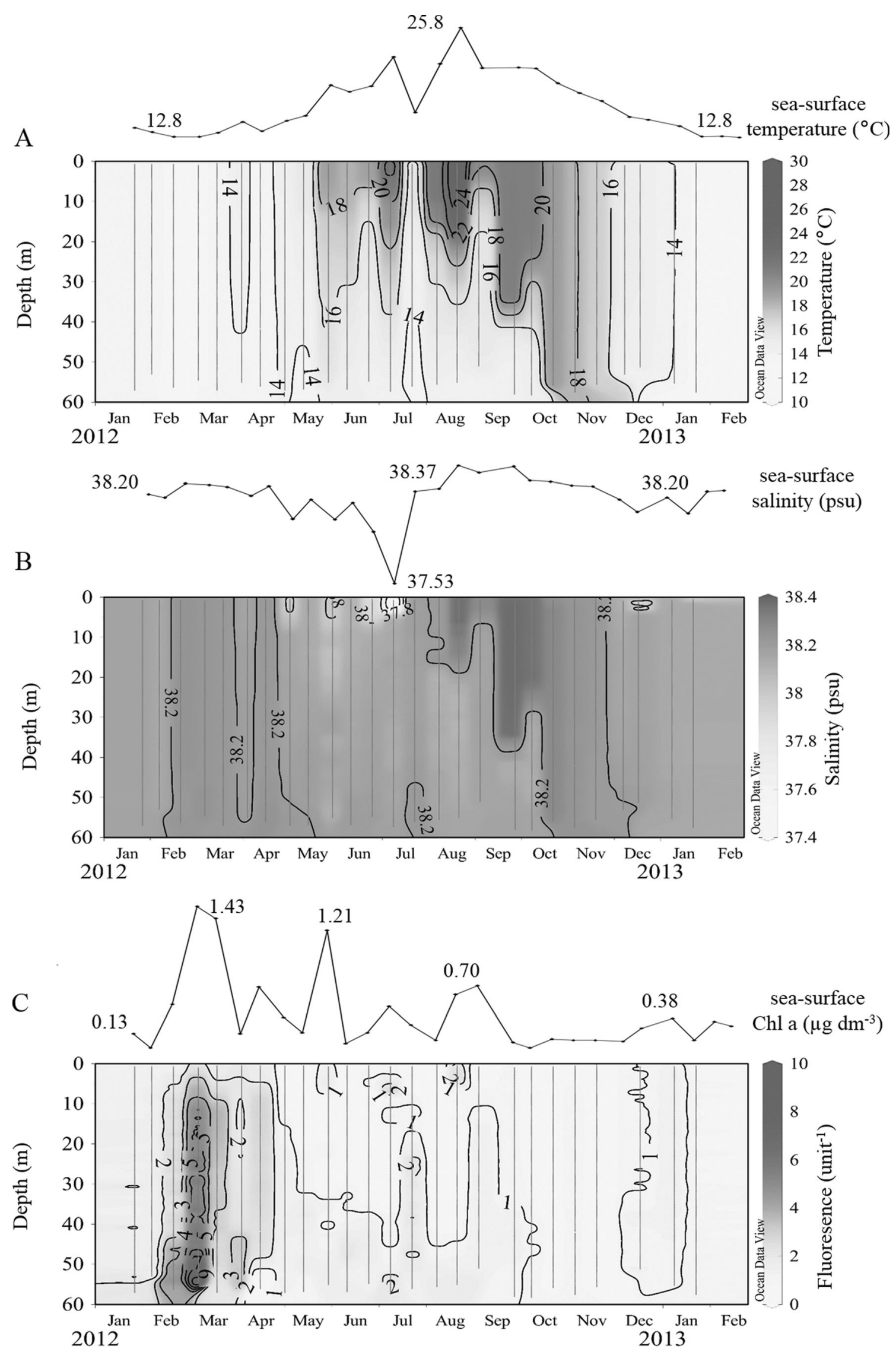
Fig. 3 (a) Temperature, (b) salinity and (c) fluorescence vertical profiles at SOLEMIO station during the survey (January 2012 to February 2013). Dots indicate sampling depths. Above contour plots show sea surface discrete temperature, salinity and $\mathrm{Chl} a$ time series (courtesy of SOMLIT data base)

temperature independently to $\mathrm{Chl} a$ ( $r$ (BP-in situ temperature $=0.76, d f=23, p<0.001 ; r(\mathrm{BR}$-in situ temperature $)=$ $0.62, d f=14, p<0.05 ; r$ (phos-in situ temperature $)=0.79, d f=$ 23, $p<0.001$ ); and (3) only BP was correlated to Chl $a$ independently to in situ temperature $(r(\mathrm{BP}-\mathrm{Chl} a)=0.62$, $d f=23, p<0.01)$.

Bacterial response to nutrient enrichment The highest increase in BP relative to the control was recorded in the PNC-amended bottles and ranged from $\times 0.7$ to $\times 40.6$ (Table 4). Overall, there was a significant stimulation in BP following $\mathrm{P}$ addition (in 7 out of the 14 surveys) while only one stimulation was observed from $\mathrm{N}$ addition (February 2013) and two cases from $C$ addition (January 2012 and October). BP was significantly stimulated when two different nutrients were added: PC in March and April and PN, NC in December. It was never necessary to add the three elements PNC together to trigger a stimulation of BP.

\section{Discussion}

Heterotrophic bacterial activity and $B G E$ Overall, the range of $\mathrm{BP}$ and $\mathrm{CR}$ recorded at the long-term coastal observatory SOLEMIO station (from 0.01 to $0.82 \mu \mathrm{g} \mathrm{C} \mathrm{dm}{ }^{-3} \mathrm{~h}^{-1}$ and from 0.11 to $2.32 \mu \mathrm{g} \mathrm{C} \mathrm{dm}{ }^{-3} \mathrm{~h}^{-1}$, respectively) were close to BP and BR encountered at the coastal observatory of Blanes bay (NW Mediterranean Bay) (from 0.01 to $0.85 \mu \mathrm{g} \mathrm{C} \mathrm{dm}{ }^{-3} \mathrm{~h}^{-1}$ and from 0.17 to $2.00 \mu \mathrm{g} \mathrm{C} \mathrm{dm}{ }^{-3} \mathrm{~h}^{-1}$, respectively) (AlonsoSáez et al. 2008). However, prot hydrolysis rates at SOLEMIO (5.1 to $85.1 \mathrm{nmol} \mathrm{dm} \mathrm{d}^{-3} \mathrm{~h}^{-1}$ ) were lower when compared with the Blanes station (from 133 to $1150 \mathrm{nmol} \mathrm{dm}^{-3} \mathrm{~h}^{-1}$ ). The difference could be that we measured $V m$ kinetics with concen-

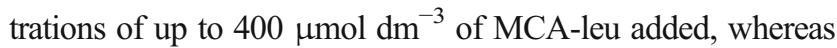
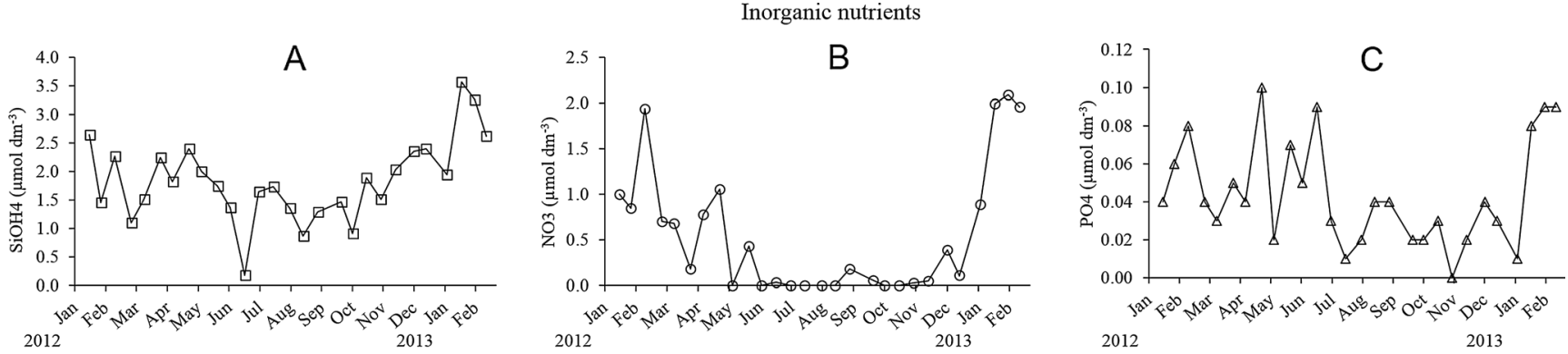

Dissolved organic matter
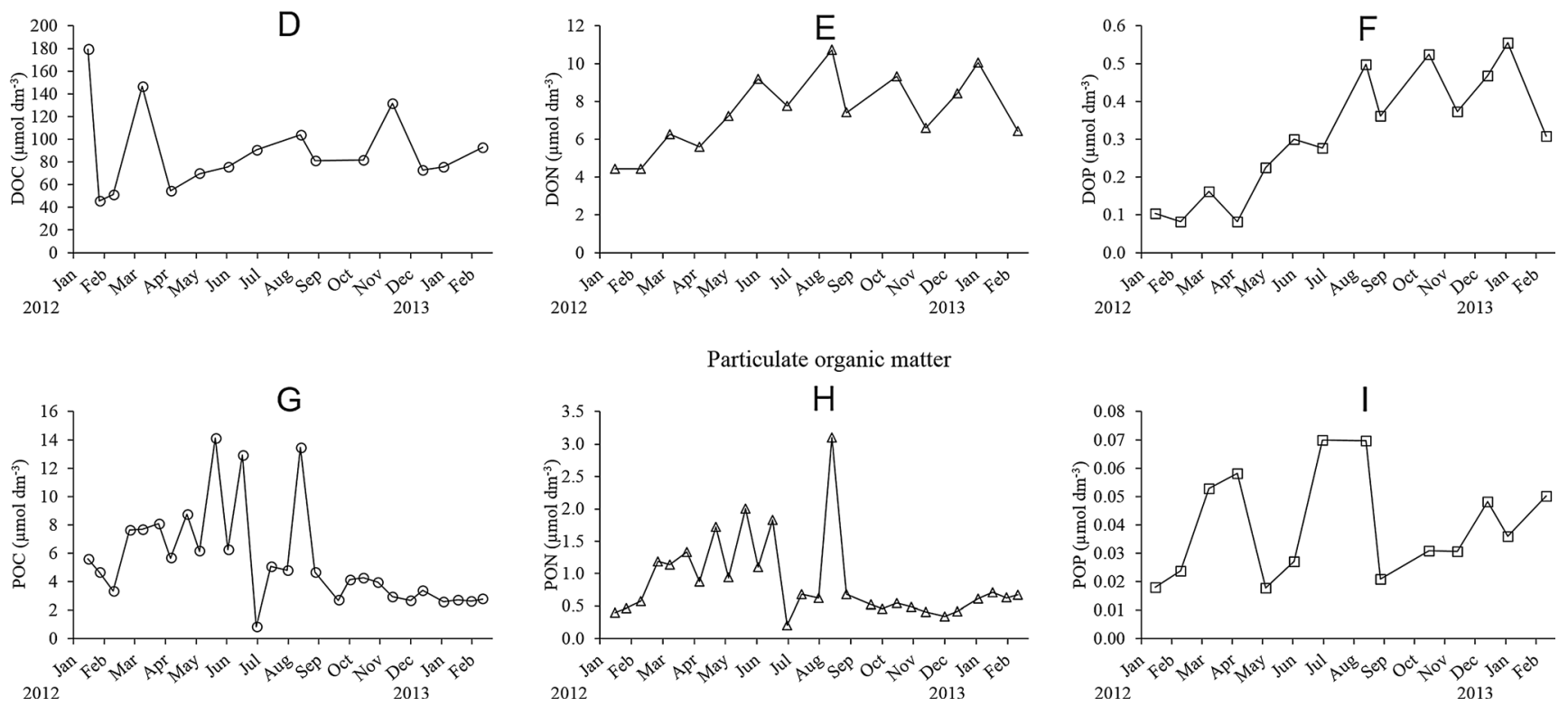

Fig. 4 Concentrations of (1) inorganic nutrients: orthosilicic acid (a), nitrate (b) and phosphate (c); (2) dissolved organic matter: DOC (d), DON (e) and DOP (f); and (3) particulate organic matter: POC (g), PON (h) and POP (i) at the SOLEMIO station during the survey 

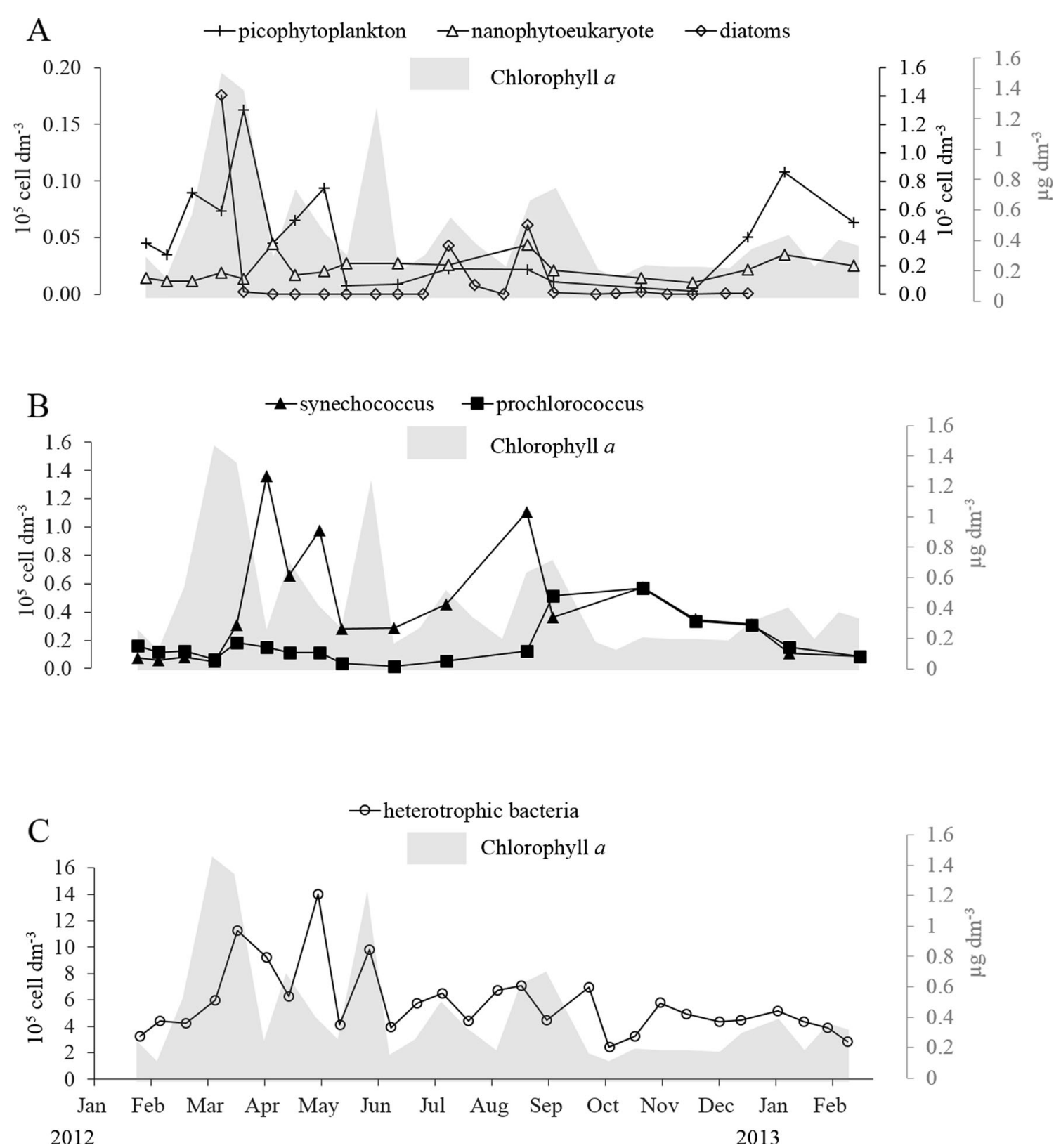

Fig. 5 Time series of abundance of (a) picophytoplankton, nanophytoeukaryote and diatoms, (b) cyanobacteria and (c) heterotrophic bacteria with Chl $a$ at the SOLEMIO station during the survey

they used $100 \mu \mathrm{mol} \mathrm{dm}{ }^{-3}$ as a single concentration. Even relative to bacteria abundance, activities were low, as reflected by cell-specific MCA-Leu hydrolysis rates at the SOLEMIO station. This may reflect the difference in trophic status between the two stations. The Blanes bay has been shown to be mesotrophic whereas the Marseille Bay is more oligotrophic (Chl a $0.95 \pm 0.22 \mu \mathrm{g} \mathrm{dm}^{-3}$ vs. $0.43 \pm 0.07 \mu \mathrm{g} \mathrm{dm}^{-3}, \mathrm{PO}_{4} 0.07 \pm$ $0.01 \mu \mathrm{mol} \mathrm{dm}{ }^{-3}$ vs. $0.04 \pm 0.01 \mu \mathrm{mol} \mathrm{dm}{ }^{-3}, \mathrm{NO}_{3} 1.81 \pm$ $0.63 \mu \mathrm{mol} \mathrm{dm}{ }^{-3}$ vs. $0.55 \pm 0.13 \mu \mathrm{mol} \mathrm{dm}{ }^{-3}$, respectively) (Alonso-Sáez et al. 2008; Simó et al. 2009). The range of BP and $\mathrm{CR}$ at the SOLEMIO station were similar to those found at the oligotrophic JGOFS-DYFAMED observatory, situated 28 miles offshore (from undetectable to $0.20 \mu \mathrm{g} \mathrm{C} \mathrm{dm}{ }^{-3} \mathrm{~h}^{-1}$ and from 0.00 to $2.59 \mu \mathrm{g} \mathrm{C} \mathrm{dm}{ }^{-3} \mathrm{~h}^{-1}$, respectively), where prot activity remained low throughout the year (mean of $4.6 \pm$ $1.5 \mathrm{nmol} \mathrm{dm}{ }^{-3} \mathrm{~h}^{-1}$ ) (Lemée et al. 2002; Van Wambeke et al. 2009). The annual mean value (17 $\pm 2 \%$ ) for BGE found at the SOLEMIO station was close to other studies in NW Mediterranean (Vázquez-Domínguez et al. 2007; Lemée et al. 2002; Alonso-Sáez and Gasol 2007), while Kritzberg et al. (2010a) observed much higher values (32\%, Table 5). Such comparisons may take into consideration (1) FC and $\mathrm{RQ}$ are different according to the studies, (2) both leucine conversion factors and BR/CR ratios have been shown to vary throughout the seasons (Alonso-Sáez and Gasol 2007; Alonso-Sáez et al. 2008; Aranguren-Gassis et al. 2012) and 


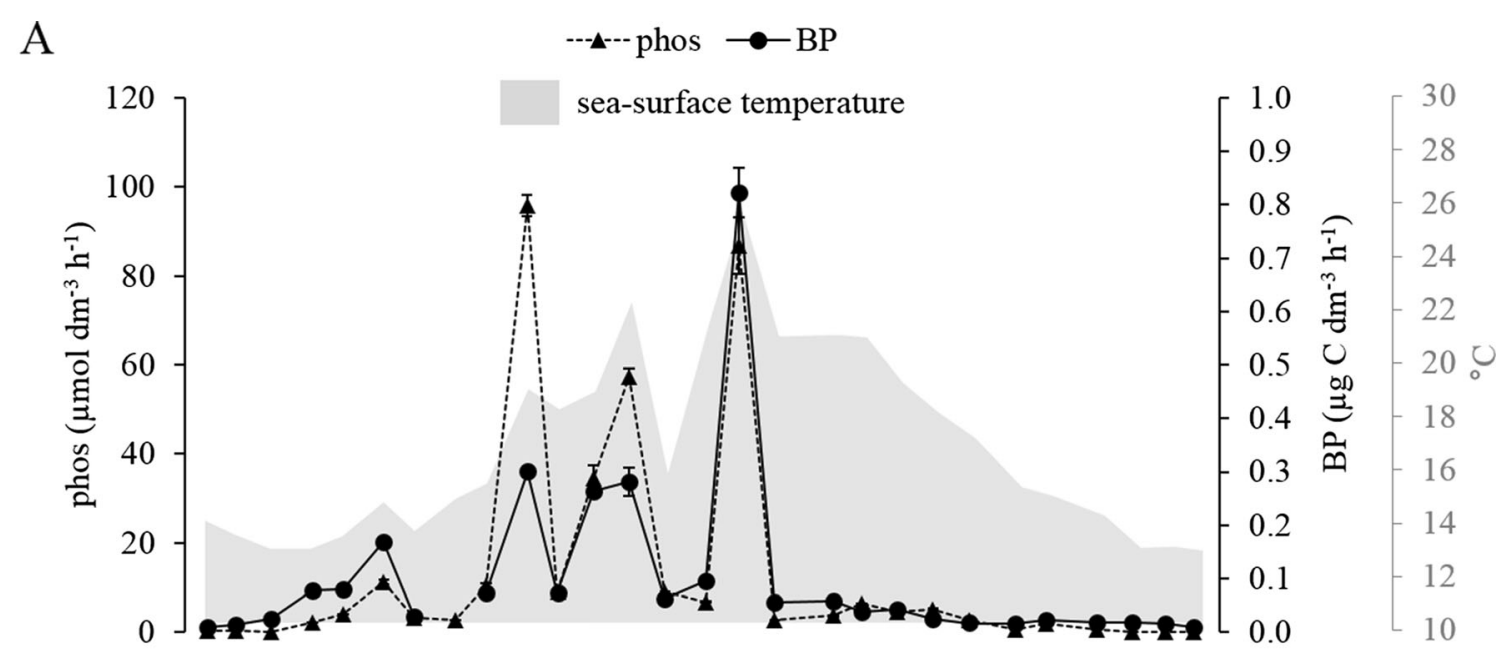

B

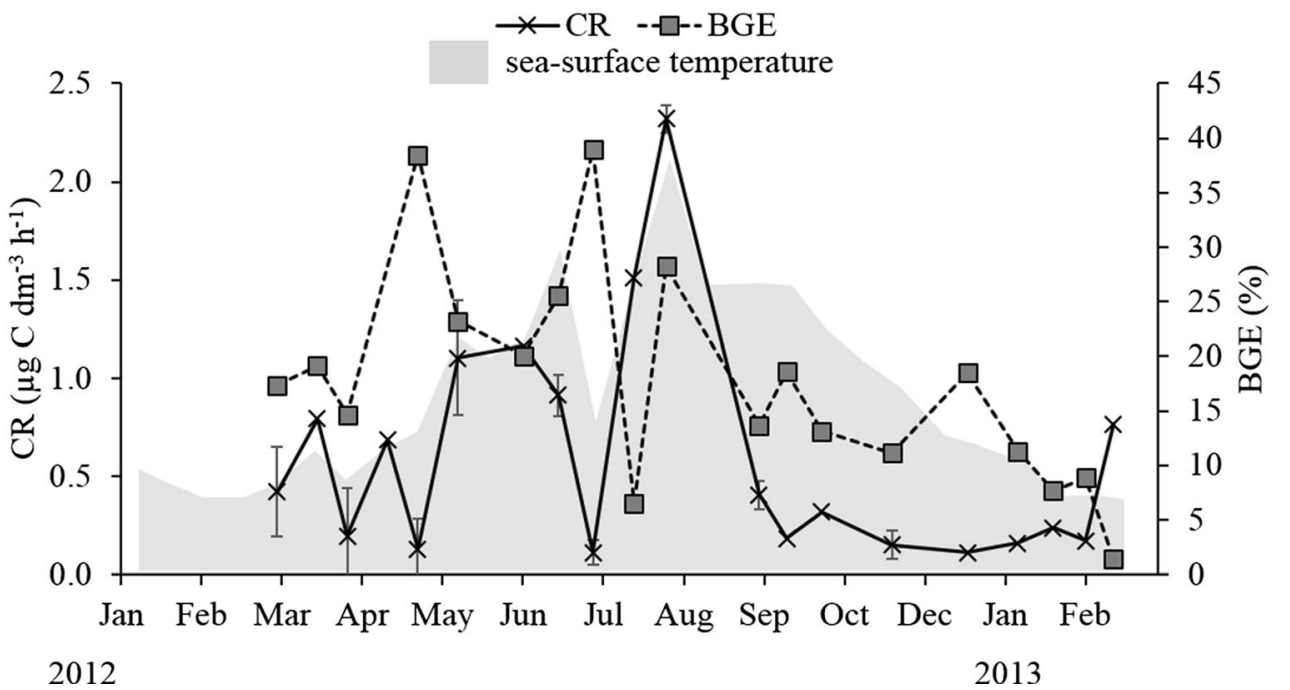

Fig. 6 Time series of (a) bacterial production and phosphatase activity and (b) community respiration and bacterial growth efficiency $(\mathrm{BGE}=\mathrm{BP} /(\mathrm{BP}+$ $0.9 \times \mathrm{CR})$ ) with sea-surface temperature at the SOLEMIO station during the survey

Table 2 Maximum hydrolysis rates $(\mathrm{Vm})$ and half saturation constant $(\mathrm{Km})$ of prot and phos measured during the survey (January 2012 to February 2013)

\begin{tabular}{|c|c|c|c|c|}
\hline \multirow[t]{2}{*}{ Time } & \multicolumn{2}{|l|}{ Prot } & \multicolumn{2}{|l|}{ Phos } \\
\hline & $\operatorname{Vm}\left(\mathrm{nmol} \mathrm{dm} \mathrm{m}^{-3} \mathrm{~h}^{-1}\right)$ & $\mathrm{Km}\left(\mu \mathrm{mol} \mathrm{dm}{ }^{-3}\right)$ & $\operatorname{Vm}\left(\mathrm{nmol} \mathrm{dm} \mathrm{m}^{-3} \mathrm{~h}^{-1}\right)$ & $\mathrm{Km}\left(\mu \mathrm{mol} \mathrm{dm}{ }^{-3}\right)$ \\
\hline March 12 & $45.6( \pm 5.2)$ & $102.1( \pm 31.1)$ & $4.3( \pm 0.3)$ & $114.0( \pm 24.6)$ \\
\hline April 12 & $12.4( \pm 0.6)$ & $40.1( \pm 6.3)$ & $3.6( \pm 0.1)$ & $111.8( \pm 12.0)$ \\
\hline May 12 & $21.8( \pm 4.1)$ & $122.5( \pm 56.4)$ & $11.3( \pm 0.4)$ & $117.9( \pm 14.0)$ \\
\hline July 12 & $85.1( \pm 4.2)$ & $83.1( \pm 11.4)$ & $67.5( \pm 2.6)$ & $145.7( \pm 17.4)$ \\
\hline August 12 & $81.3( \pm 5.9)$ & $63.6( \pm 14.0)$ & $115.7( \pm 2.7)$ & $346.1( \pm 19.5)$ \\
\hline September 12 & $12.2( \pm 0.7)$ & $67.2( \pm 11.0)$ & $3.0( \pm 0.2)$ & $163.0( \pm 37.1)$ \\
\hline October 12 & $14.5( \pm 0.8)$ & $62.1( \pm 10.0)$ & $4.8( \pm 0.3)$ & $131.0( \pm 23.0)$ \\
\hline November 12 & $7.39( \pm 0.9)$ & $41.8( \pm 17.5)$ & $2.9( \pm 0.4)$ & $47.1( \pm 83.2)$ \\
\hline December 12 & $7.28( \pm 0.5)$ & $42.2( \pm 10.0)$ & $2.6( \pm 0.8)$ & $471.2( \pm 318.1)$ \\
\hline January 13 & $16.9( \pm 2.9)$ & $151.2( \pm 59.3)$ & $0.7( \pm 0.1)$ & $65.0( \pm 33.6)$ \\
\hline February 13 & $5.1( \pm 0.3)$ & $35.5( \pm 8.5)$ & $0.1( \pm 0.0)$ & $273.8( \pm 86.3)$ \\
\hline
\end{tabular}


Table 3 Partial correlation coefficients between in situ temperature, Chl $a$, phos, prot, $\mathrm{BP}$ and $\mathrm{BR}$ calculated from log-transformed data with probability values of $p<0.05(*), p<0.01(* *)$ and $p<0.001(* * *)$. Values in bracket are the degree of freedom for each partial correlation

\begin{tabular}{lllll}
\hline & Phos & Prot & BP & BR \\
\hline Phos & nd & & & \\
Prot & $-0.45(4)$ & nd & & \\
BP & $0.91^{* *}(4)$ & $0.74(4)$ & nd & \\
BR & $-0.76(4)$ & $-0.43(4)$ & $0.79(4)$ & nd \\
In situ temperature & $0.79 * * *(23)$ & $0.66(6)$ & $0.76^{* * *}(23)$ & $0.62(14)$ \\
Chl $a$ & $0.46(23)$ & $0.62(6)$ & $0.62 * *(23)$ & $0.32 *(14)$ \\
\hline
\end{tabular}

(3) the comparisons of prot is dependent on the choice of the final concentration of Leu-MCA (50 to $400 \mu \mathrm{mol} \mathrm{dm}{ }^{-3}$ according above authors).

The effect of nutrients and labile carbon limitation The range of phos found at SOLEMIO was similar to that found in the open Mediterranean Sea along two longitudinal transects during June and July 1999 (from 0.62 to $12.60 \mathrm{nmol} \mathrm{dm}^{-3} \mathrm{~h}^{-1}$ ) (Van Wambeke et al. 2002). The very low $\mathrm{PO}_{4}$ concentrations and the higher phos activity from May to August suggested $\mathrm{P}$ limitation during summer. The cell specific phos hydrolysis rate increased from May to August as did the other activities, suggesting that phos activity did not depended on bacterial

Table 4 Enrichment factors relative to the corresponding unamended control after $48 \mathrm{~h}$ of incubation

\begin{tabular}{llllllll}
\hline Time & xP & xN & $x C$ & $x P N$ & $x P C$ & $x N C$ & $x P N C$ \\
\hline January 12 & 0.7 & 1.0 & $4.2^{\mathrm{a}}$ & 1.0 & $4.5^{\mathrm{a}}$ & $4.1^{\mathrm{a}}$ & $9.1^{\mathrm{a}}$ \\
February 12 & 1.0 & 1.3 & 1.1 & 0.9 & 1.1 & 2.1 & $1.4^{\mathrm{a}}$ \\
March 12 & 2.3 & 1.0 & 1.2 & 2.0 & $6.3^{\mathrm{a}}$ & 1.3 & $8.3^{\mathrm{a}}$ \\
April 12 & 1.2 & 1.1 & 1.0 & 1.3 & $10.3^{\mathrm{a}}$ & 0.9 & $7.1^{\mathrm{a}}$ \\
May 12 & $10.0^{\mathrm{a}}$ & 0.8 & 0.7 & $13.6^{\mathrm{a}}$ & $11.4^{\mathrm{a}}$ & 0.8 & $18.0^{\mathrm{a}}$ \\
Jun 12 & $4.9^{\mathrm{a}}$ & 0.8 & 0.8 & $12.7^{\mathrm{a}}$ & $4.7^{\mathrm{a}}$ & 1.0 & 0.9 \\
July 12 & $3.7^{\mathrm{a}}$ & 1.0 & 1.0 & $10.0^{\mathrm{a}}$ & $7.6^{\mathrm{a}}$ & $1.3^{\mathrm{a}}$ & $11.1^{\mathrm{a}}$ \\
August 12 & $6.0^{\mathrm{a}}$ & 1.5 & 1.4 & $6.4^{\mathrm{a}}$ & $5.2^{\mathrm{a}}$ & 1.0 & $8.0^{\mathrm{a}}$ \\
September 12 & $2.5^{\mathrm{a}}$ & 1.2 & 1.1 & $3.6^{\mathrm{a}}$ & $2.6^{\mathrm{a}}$ & 0.9 & $4.1^{\mathrm{a}}$ \\
October 12 & $15.4^{\mathrm{a}}$ & 1.1 & $1.2^{\mathrm{a}}$ & $23.8^{\mathrm{a}}$ & $13.8^{\mathrm{a}}$ & 0.9 & $25.7^{\mathrm{a}}$ \\
November 12 & $7.3^{\mathrm{a}}$ & 0.8 & 1.1 & $38.3^{\mathrm{a}}$ & $16.5^{\mathrm{a}}$ & 0.5 & $40.6^{\mathrm{a}}$ \\
December 12 & 1.2 & 1.1 & 0.9 & $4.0^{\mathrm{a}}$ & 1.1 & $1.7^{\mathrm{a}}$ & $17.6^{\mathrm{a}}$ \\
January 13 & 0.8 & 1.3 & 0.9 & 1.7 & 1.3 & 0.9 & $3.7^{\mathrm{a}}$ \\
February 13 & 0.8 & $1.8^{\mathrm{a}}$ & 1.0 & $\mathrm{nd}$ & 1.8 & 1.2 & $\mathrm{nd}$ \\
\hline
\end{tabular}

$x P: \mathrm{PO}_{4}$ alone, $x N: \mathrm{NO}_{3}+\mathrm{NH}_{4}, x C$ : glucose alone, $x P N: \mathrm{PO}_{4}+\mathrm{NO}_{3}+$ $\mathrm{NH}_{4}, x P C: \mathrm{PO}_{4}+$ glucose, $x N C: \mathrm{NO}_{3}+\mathrm{NH}_{4}+$ glucose, $x P N C: \mathrm{PO}_{4}+$ $\mathrm{NO}_{3}+\mathrm{NH}_{4}+$ glucose

${ }^{\mathrm{a}}$ Rate of BP after $48 \mathrm{~h}$ of amendment significantly different from that in the unamended control ( $t$ test, $p<0.05$ and $d f=4$ ) abundance only. Indeed both phoA and phoX genes can be induced by heterotrophic and photosynthetic prokaryotes during P limitation (Sebastian and Ammerman 2009), suggesting that all categories of organisms possessing these genes could be responsible for the phosphatase activity, as both are good markers of P stress conditions. Furthermore, enrichment experiments showed that phosphate limitation occurred over a longer time period, from March to November 2012. Labile carbon was added (glucose) during the enrichment experiments, alone or in combinations with $\mathrm{N}$ and $\mathrm{P}$. BP in SOLEMIO was stimulated by labile carbon (i.e. glucose) alone, only in January 2012, but not during winter 2013. This suggests that, even under winter mixing conditions, labile carbon is not always the first limiting factor. $\mathrm{P}$ is the main limiting element; $\mathrm{N}$ is the second limiting element except in March and April where labile $\mathrm{C}$ is the second limiting element. Thus, our ecosystem is mainly P-limited. So far, we have no more arguments to say that the lability of DOC in terms or quality of C-organic molecules would influence BP more than the accessibility to $\mathrm{N}$ and $\mathrm{P}$ pools. The $48 \mathrm{~h}$ of confinement in the dark may be sufficient to create $\mathrm{P}$ stress as in situ organisms probably used $\mathrm{P}$ at a steady rate of delivery in these intermediary periods in March, May and AugustNovember.

Prior to discussing the stoichiometry of the organic matter, we have to consider the high DOC value relevance for our ecosystem study. Three high DOC concentrations found during the cruise $\left(179 \mu \mathrm{mol} \mathrm{\textrm {dm } ^ { - 3 }}\right.$ in January 2012 , $147 \mu \mathrm{mol} \mathrm{dm}{ }^{-3}$ in March 2012 and $132 \mu \mathrm{mol} \mathrm{dm}{ }^{-3}$ in November 2012 in Fig. 4d) were not related to any salinity event and thus cannot be explained by intrusion of Rhône River into the Bay of Marseille during these periods. The SOLEMIO site being situated near to the coast, some anthropogenic influence could give punctual high DOC values. However, none of our biological or biogeochemical variables were related to these three high DOC values. Hence, we could not reject potential problem in contamination of some samples. Therefore, these three high values of DOC are removed, and the new mean annual value of DOC is of $75 \pm$ $5 \mu \mathrm{mol} \mathrm{dm}{ }^{-3}$ at $5 \mathrm{~m}$, close to that of $67 \pm 7 \mu \mathrm{mol} \mathrm{dm}{ }^{-3}$ at $2 \mathrm{~m}$ found by Para et al. (2010) during the year 2007-2008.

Carbon, nitrogen and phosphate stoichiometry of the dissolved organic matter was also higher than the Redfield ratio (DOC/DOP ratio range from 136 to 664, and with an average of 306, also DON/DOP ratio range from 18 to 68, and with an average of 31). Seasonal evolution of the particulate matter $\mathrm{P}$ stoichiometry was very variable $(\mathrm{CV} \mathrm{C} / \mathrm{P} 64 \%, \mathrm{CV}$ N/P $61 \%$ ), but ratios were always greater than the Redfield ratio, while the evolution of $\mathrm{C} / \mathrm{N}$ was more steady over the year (32\%). All these results converged to a $\mathrm{P}$ limitation at the coastal oligotrophic SOLEMIO station for most of the year. In a marine ecosystem with $\mathrm{P}$ limitation, the $\mathrm{P}$ availability can limit both growth (Van Wambeke et al. 2002) and respiration 
Table 5 Summary of bacterial growth efficiency (BGE) found by several authors in NW Mediterranean Sea

\begin{tabular}{lllllll}
\hline Authors & Study area & FC & RQ & & \multirow{2}{*}{ BGE (\%) } \\
\cline { 4 - 7 } & & & & Min & Max & Average \pm SE \\
\hline This study & Marseille's Bay & 1.5 to 2.6 & 0.8 & 1 & 37 & $17 \pm 2$ \\
Kritzberg et al. 2010a & Island of Majorca & 1.5 & 1 & 12 & 51 & $32 \pm 3$ \\
Alonso-Sáez et al. 2008 & Blanes Bay & 0.9 to 3.6 & 0.88 & 3 & 42 & $17 \pm 4$ \\
Vázquez-Domínguez et al. 2007 & Blanes Bay & 3.1 & 1 & nd & nd & $18 \pm 6$ \\
Lemée et al. 2002 & DYFAMED & 1.5 & 1 & 0.1 & 43 & $11 \pm 2$ \\
\hline
\end{tabular}

$F C$ leucine-carbon conversion factor (kilograms $\mathrm{C}$ per mole leucine ${ }^{-1}$ ), $R Q$ respiratory quotient

(Obernosterer et al. 2003). In our study, we found a positive correlation between BP and phos, but also between BP and $\mathrm{Chl} a$, whereas BR was not correlated to Chl $a$. These results suggested that BP was more resource-dependent, relative to $\mathrm{BR}$, as previously suggested (López-Urrutia and Morán 2007). Phosphate is necessary for protein synthesis, cell production and energy transport by bacteria (Kritzberg et al. 2010a). In deep sea environments, it has been suggested that phosphatase activity facilitates the hydrolysis of refractory molecules, giving them access to $\mathrm{N}$ or $\mathrm{C}$ for degradation by other enzymes (Hoppe 2003). The presence of both prot and phos may favour access to organic matter (Hoppe et al. 1988). The phos/prot ratio has been proposed as a relevant physiological indicator of the nutritional status of a biological system (Sala et al. 2001). In this study, the phos/prot ratio increased with the P-deficient nutrient addition but decreased in the $\mathrm{N}+$ $\mathrm{P}$ balanced additions. This ratio increased from March to August when P limitation occurred and decreased over the rest of the year. These results suggest that phos and prot could give an ecological advantage to microorganisms capable of consuming organic matter when it is poor or refractory.

Temperature effect Besides organic matter stoichiometry and lability, temperature impacted bacterial activity, as depicted by the significant positive correlation between in situ temperature and phos, BP and BR. The influence of temperature may not have the same impact on BP and BR, but generally resulted in a decrease in BGE (Daneri et al. 1994; Rivkin and Legendre 2001; Apple et al. 2006; Berggren et al. 2010). For example, a seasonal study (March 2000 to January 2002) of 13 stations within a temperate estuary (ranging from 3 to $30{ }^{\circ} \mathrm{C}$, Chesapeake Bay, USA), carried out by Apple et al. (2006), revealed that BR was mainly controlled by temperature, whereas both temperature and organic matter quality influenced $\mathrm{BP}$ and $\mathrm{BGE}$ resulting in a negative temperature response of BGE while another seasonal study by Kritzberg et al. (2010a) carried out between 2005 and 2008 in Majorca (Spain), where the temperature of the surface water varied between 14.4 and $28.2^{\circ} \mathrm{C}$, showed a significant relationship with in situ temperature for $\mathrm{BR}$ and $\mathrm{BP}$. The authors concluded that BP and BR are both affected by temperature, but BR more than BP. In our study, we could not find any relationship between $\mathrm{BGE}$ and temperature. However, the increase of BGE from May to late July coincided with the increase of BP and mostly with the strong increase of prot, thus resulting in a bacterial uptake of polymeric organic matter. Compiling several BGE data, Del Giorgio and Cole (1998) concluded that an unexplained source of BGE variability was due to the regional and seasonal differences of quality and quantity of the organic matter. From winter to summer, bacterial activity varied more than twofold suggesting that temperature alone would not be sufficient to explain the variation of BP, BR, prot and phos. In the natural ecosystem, several parameters can act on these activities such as the availability of resources, predation, viruses or bacteria community composition (del Giorgio and Cole 1998; Cottrell and Kirchman 2000; Fischer and Velimirov 2002; Apple et al. 2006). Temperature could affect various processes within the microbial food web differently, like BP, BR, grazing or lytic activities (Sarmento et al. 2010; Bouvy et al. 2011). So, the controlling factors of one process within an ecosystem, such as temperature, can only start to be understood by monitoring the multiple indirect interactions. The coupling can be assessed through sensitivity estimates of temperature control together with resource control on the heterotrophic activities during the season. Because in natural environments temperature and resource controls are interacting together, it is necessary to get proper experimental data on the simultaneous effects of temperature $\left(Q_{10}\right)$ on both production and respiration. This is further developed in a companion study (Céa et al. under review).

Conclusion The simultaneous measurements of four different heterotrophic bacterial activities and BGEs with biogeochemical parameters helped to highlight their strong variation throughout the season in relation to resources and temperature control. These data clearly showed the wide range of BGE that can be experienced at a particular site on an annual timescale in the surface mixed layer. Our results confirmed that the availability of phosphate and temperature were the main 
factors controlling heterotrophic activity in the coastal, oligotrophic Marseille Bay. Further insight on the ecosystem dynamics should be improved using regional modelling (Fraysse et al. 2013) and by using high-frequency long-term observation systems including biological observation and proxies in relation to environmental variables (Thyssen et al. 2008).

Acknowledgements This work was supported by the EC2CO (Ecosphère Continentale et Cotière) program and DEMO2 (Dégradation de la Matière Organique) project. We are very grateful to the crew of the R/V Antedon II for their excellent service at sea and the SOMLIT staff for providing CTD data from SOLEMIO. Ph.D. scholarship to B. Céa was provided by the Provence Alpes Côte d'Azur region. We also wish to thank Beatrice Beker for her data of the microphytoplankton and Christophe Yohia for his wind direction compass. Special thanks go to Karine Le Blanc, Bernard Queguiner the CYBELE team from MIO for their helpful comments. We are grateful to Dr. Philippe Garrigues for helpful comments on the manuscript and to the reviewer for their useful criticisms. This is a contribution to the SOMLIT network.

\section{References}

Alonso-Sáez L, Gasol JM (2007) Seasonal variations in the contributions of different bacterial groups to the uptake of low-molecular-weight compounds in northwestern Mediterranean coastal waters. Appl Environ Microbiol 73:3528-3535

Alonso-Sáez L, Vázquez-Domínguez E, Cardelús C, Pinhassi J, Sala MM, Lekunberri I, Balagué V, Vila-Costa M, Unrein F, Massana R, Simó R, Gasol JM (2008) Factors controlling the year-round variability in carbon flux through bacteria in a coastal marine system. Ecosystems 11:397-409

Aminot A, Kérouel R (2004) Dissolved organic carbon, nitrogen and phosphorus in the N-E Atlantic and the N-W Mediterranean with particular reference to non-refractory fractions and degradation. Deep Sea Res Part I Oceanogr Res Pap 51:1975-1999

Apple JK, del Giorgio PA, Kemp WM (2006) Temperature regulation of bacterial production, respiration, and growth efficiency in a temperate salt-marsh estuary. Aquat Microb Ecol 43:243-254

Aranguren-Gassis M, Teira E, Serret P, Martínez-García S, Fernández E (2012) Potential overestimation of bacterial respiration rates in oligotrophic plankton communities. Mar Ecol Prog Ser 453:1-10

Berggren M, Laudon H, Jonsson A, Jansson M (2010) Nutrient constraints on metabolism affect the temperature regulation of aquatic bacterial growth efficiency. Microb Ecol 60:894-902

Bouvy M, Bettarel Y, Bouvier C, Domaizon I, Jacquet S, Le Floc'h E, Montanié H, Mostajir B, Sime-Ngando T, Torréton JP, Vidussi F, Bouvier T (2011) Trophic interactions between viruses, bacteria and nanoflagellates under various nutrient conditions and simulated climate change. Environ Microbiol 13:1842-1857

Broche P, Devenon J-L, Forget P, de Maistre J-C, Naudin J-J, Cauwet G (1998) Experimental study of the Rhone plume. Part I: physics and dynamics. Oceanol Acta 21:725-738

Cauwet G (1994) HTCO method for dissolved organic carbon analysis in seawater: influence of catalyst on blank estimation. Mar Chem 47: $55-64$

Céa B, VanWambeke F, Lefèvre D, Chirurgien L (under review) How temperature and resources affect activities of marine heterotrophic bacteria? A seasonal study in Marseille's Bay. Aquat Microb Ecol

Christakill U, Van Wambeke F, Dolan JR (1999) Nanoflagellates (mixotrophs, heterotrophs and autotrophs) in the oligotrophic eastern Mediterranean: standing stocks, bacterivory and relationships with bacterial production. Mar Ecol Prog Ser 181:297-307

Cole JJ, Pace ML (1995) Bacterial secondary production in oxic and anoxic freshwaters. Limnol Oceanogr 40:1019-1027

Cotner JB, Ammerman JW, Peele ER, Bentzen E (1997) Phosphoruslimited bacterioplankton growth in the Sargasso Sea. Aquat Microb Ecol 13:141-149

Cottrell MT, Kirchman DL (2000) Natural assemblages of marine proteobacteria and members of the Cytophaga-Flavobacter cluster consuming low- and high-molecular-weight dissolved organic matter. Appl Environ Microbiol 66:1692-1697

Daneri G, Riemann B, Williams PJL (1994) In-situ bacterial production and growth-yield measured by thymidine, leucine and fractionated dark oxygen-uptake. J Plankton Res 16:105-113

del Giorgio PA, Cole JJ (1998) Bacterial growth efficiency in natural aquatic systems. Annu Rev Ecol Syst 29:503-541

del Giorgio PA, Williams PJ (2005) Respiration in aquatic ecosystems. Oxford University Press, Oxford, pp 1-17

Del Negro P, Celussi M, Crevatin E, Paoli A, Aubry FB, Pugnetti A (2008) Spatial and temporal prokaryotic variability in the northern Adriatic Sea. Mar Ecol 29:375-386

Estournel C, Broche P, Marsaleix P, Devenon J-L, Auclair F, Vehil R (2001) The Rhone River plume in unsteady conditions: numerical and experimental results. Estuar Coast Shelf Sci 53:25-38

Fischer U, Velimirov B (2002) High control of bacterial production by viruses in a eutrophic oxbow lake. Aquat Microb Ecol 27:1-12

Fraysse M, Pinazo C, Faure VM, Fuchs R, Lazzari P, Raimbault P, Pairaud I (2013) Development of a 3D coupled physicalbiogeochemical model for the Marseille coastal area (NW Mediterranean Sea): what complexity is required in the coastal zone? PLoS ONE 8:e80012

Fraysse M, Pinazo C, Pairaud I (2014) Rôle du forçage physique sur l'écosystème à l'est du Golfe du Lion: Modulation de l'impact des apports anthropiques en sels nutritifs et matière organique étudiée par modélisation 3D couplée physique et biogéochimique, $\mathrm{pH}-\mathrm{D}$ Thesis, Aix-Marseille University, $339 \mathrm{pp}$

Fraysse M, Pairaud I, Ross ON, Faure VM, Pinazo C (under review) Intrusion of Rhone River diluted water into the bay of Marseille: generation processes and impacts on ecosystem functioning. Geophys Res

Gatti J (2008) Intrusions du courant nord méditerranéen sur la partie est du plateau continental du golfe du Lion.

Gatti J, Petrenko A, Devenon J-L, Leredde Y, Ulses C (2006) The Rhone River dilution zone present in the northeastern shelf of the Gulf of Lion in December 2003. Cont Shelf Res 26:1794-1805

Grégori G, Colosimo A, Denis M (2001) Phytoplankton group dynamics in the Bay of Marseilles during a 2-year survey based on analytical flow cytometry. Cytometry 44:247-256

Hoppe HG (1983) Signifiance of exoenzymatic activities in the ecology of brackish water: measurements by means of methylumbelliferylsubstrates. Mar Ecol Prog Ser 11:299-308

Hoppe HG (2003) Phosphatase activity in the sea. Hydrobiologia 493: $187-200$

Hoppe H, Kim S, Gocke K (1988) Microbial decomposition in aquatic environments: combined process of extracellular enzyme activity and substrate uptake. Appl Environ Microbiol 54:784-790

Jahnke RA, Craven DB (1995) Quantifying the role of heterotrophic bacteria in the carbon cycle: a need for respiration rate measurements. Limnol Oceanogr 40:436-441

Kirchman D, K'nees E, Hodson R (1985) Leucine incorporation and its potential as a measure of protein synthesis by bacteria in natural aquatic systems. Appl Environ Microbiol 49:599-607

Kragh T, Søndergaard M, Tranvik L (2008) Effect of exposure to sunlight and phosphorus-limitation on bacterial degradation of coloured dissolved organic matter (CDOM) in freshwater. FEMS Microbiol Ecol 64:230-239 
Kritzberg E, Arrieta J, Duarte C (2010a) Temperature and phosphorus regulating carbon flux through bacteria in a coastal marine system. Aquat Microb Ecol 58:141-151

Kritzberg ES, Duarte CM, Wassmann P (2010b) Changes in Arctic marine bacterial carbon metabolism in response to increasing temperature. Polar Biol 33:1673-1682

Kroer N (1993) Bacterial growth efficiency on natural dissolved organic matter. Limnol Oceanogr 38:1282-1290

Krom MD, Kress N, Brenner S, Gordon LI (1991) Phosphorus limitation of primary productivity in the eastern Mediterranean Sea. Limnol Oceanogr 36:424-432

Lami R, Ghiglione J-F, Desdevises Y, West NJ, Lebaron P (2009) Annual patterns of presence and activity of marine bacteria monitored by $16 \mathrm{~S}$ rDNA-16S rRNA fingerprints in the coastal NW Mediterranean Sea. Aquat Microb Ecol 54:199-210

Lemée R, Rochelle-Newall E, Van Wambeke F, Pizay M-D, Rinaldi P, Gattuso J-P (2002) Erratum: seasonal variation of bacterial production, respiration and growth efficiency in the open $\mathrm{NW}$ Mediterranean Sea. Aquat Microb Ecol 29:227-237

López-Urrutia A, Morán XAG (2007) Resource limitation of bacterial production distorts the temperature dependence of oceanic carbon cycling. Ecology 88:817-822

Marie D, Partensky F, Jacquet S, Vaulot D (1997) Enumeration and cell cycle analysis of natural populations of marine picoplankton by flow cytometry using the nucleic acid stain SYBR green I. Appl Environ Microbiol 63:186-193

Massana R, Pedros-Alio C, Casamayor EO, Gasol JM (2001) Changes in marine bacterioplankton phylogenetic composition during incubations designed to measure biogeochemically significant parameters. Limnol Oceanogr 46:1181-1188

Middelboe M, Søndergaard M (1993) Bacterioplankton growth yield: seasonal variations and coupling to substrate lability and betaglucosidase activity. Appl Environ Microbiol 59:3916-3921

Millot C (1990) The Gulf of Lions' hydrodynamics. Cont Shelf Res 10: 885-894

Millot C, Wald L (1980) The effects of mistral wind on the Ligurian current near Provence. Oceanol Acta 3:399-402

Minas H (1968) A propos d'une remontée d'eaux “"profondes"” dans les parages du golfe de Marseille (oct. 1964), conséquences biologiques. Cah Oceanogr 20:647-674

Obernosterer I, Kawasaki N, Benner R (2003) P limitation of respiration in the Sargasso Sea and uncoupling of bacteria from $P$ regeneration in size-fractionation experiments. Aquat Microb Ecol 32:229-237

Para J, Coble PG, Charrière B, Tedetti M, Fontana C, Sempéré R (2010) Fluorescence and absorption properties of chromophoric dissolved organic matter (CDOM) in coastal surface waters of the northwestern Mediterranean Sea, influence of the Rhône River. Biogeosciences 7: 4083-4103

Pairaud IL, Gatti J, Bensoussan N, Verney R, Garreau P (2011) Hydrology and circulation in a coastal area off Marseille: validation of a nested 3D model with observations. J Mar Syst 88:20-33

Pinhassi J, Gómez-Consarnau L, Alonso-Sáez L, Sala M, Vidal M, PedrósAlió C, Gasol J (2006) Seasonal changes in bacterioplankton nutrient limitation and their effects on bacterial community composition in the NW Mediterranean Sea. Aquat Microb Ecol 44:241-252

Raimbault P, Slawyk G, Coste B, Fry J (1990) Feasibility of using an automated procedure for the determination of seawater nitrate in the 0-100 nM range: examples from field and cultures. Mar Biol 104: 347-351

Raimbault P, Diaz F, Pouvesle W, Boudjellal B (1999) Simultaneous determination of particulate organic carbon, nitrogen and phosphorus collected on filters, using a semi-automatic wet-oxidation method. Mar Ecol Prog Ser 180:289-295
Raimbault P, Lantoine F, Neveux J (2004) Rapid measurement of chlorophyll a and of phaeopigments a by fluorimetry after extraction with methanol. Comparison with the classic acetone extraction method. Océanis 30:189-205

Reffray G, Fraunie P, Marsaleix P (2004) Secondary flows induced by wind forcing in the Rhone region of freshwater influence. Ocean Dyn 54:179-196

Rivkin RB, Legendre L (2001) Biogenic carbon cycling in the upper ocean: effects of microbial respiration. Science 291:2398-2400

Sala MM, Karner M, Arin L (2001) Measurement of ectoenzyme activities as an indication of inorganic nutrient imbalance in microbial communities. Aquat Microb Ecol 23:301-311

Sarmento H, Montoya JM, Vazquez-Dominguez E, Vaqué D, Gasol JM (2010) Warming effects on marine microbial food web processes: how far can we go when it comes to predictions? Philos Trans R Soc Lond B Biol Sci 365:2137-2149

Sebastian M, Ammerman JW (2009) The alkaline phosphatase PhoX is more widely distributed in marine bacteria than the classical PhoA. ISME J 3:563-572

Simó R, Vila-Costa M, Alonso-Sáez L, Cardelús C, Guadayol Ò, Vázquez-Domínguez E, Gasol J (2009) Annual DMSP contribution to $\mathrm{S}$ and $\mathrm{C}$ fluxes through phytoplankton and bacterioplankton in a NW Mediterranean coastal site. Aquat Microb Ecol 57:43-55

Smith DC, Azam F (1992) A simple, economical method for measuring bacterial protein synthesis rates in seawater using $3 \mathrm{H}-$ leucine. Mar Microbial Food Webs 6:107-114

Thingstad TF, Zweifel UL, Rassoulzadegan F (1998) P limitation of heterotrophic bacteria and phytoplankton in the northwest Mediterranean. Limnol Oceanogr 43:88-94

Thyssen M, Mathieu D, Garcia N, Denis M (2008) Short-term variation of phytoplankton assemblages in Mediterranean coastal waters recorded with an automated submerged flow cytometer. J Plankton Res 30:1027-1040

Torréton J-P, Talbot V, Garcia N (2000) Nutrient stimulation of bacterioplankton growth in Tuamotu atoll lagoons. Aquat Microb Ecol 21:125-137

Tréguer P, Corre P Le (1975) Manuel d'analyse des sels nutritifs dans l'eau de mer (utilisation de l'autoAnalyseur II Technicon). Laboratoire d'Océanographie chimique, Université de bretagne occidentale

Vallino JJ, Hopkinson CS, Hobbie JE (1996) Modeling bacterial utilization of dissolved organic matter: optimization replaces Monod growth kinetics. Limnol Oceanogr 4:1591-1609

Van Wambeke F, Christaki U, Giannakourou A, Moutin T, Souvemerzoglou K (2002) Longitudinal and vertical trends of bacterial limitation by phosphorus and carbon in the Mediterranean Sea. Microb Ecol 43:119-133

Van Wambeke F, Bonnet S, Moutin T, Raimbault P, Alarc G (2008) Factors limiting heterotrophic bacterial production in the southern Pacific Ocean. Biogeosciences 5:833-845

Van Wambeke F, Ghiglione J-F, Nedoma J, Mével G, Raimbault P (2009) Bottom up effects on bacterioplankton growth and composition during summer-autumn transition in the open NW Mediterranean Sea. Biogeosciences 6:705-720

Vázquez-Domínguez E, Vaqué D, Gasol JM (2007) Ocean warming enhances respiration and carbon demand of coastal microbial plankton. Glob Chang Biol 13:1327-1334

Williams PJL, Jenkinson NW (1982) A transportable microprocessorcontrolled precise Winkler titration suitable for field station and shipboard use. Limnol Oceanogr 27:576-584

Zweifel UL, Norrman B, Hagstrom A (1993) Consumption of dissolved organic carbon by marine bacteria and demand for inorganic nutrients. Mar Ecol Prog Ser 101:23-32 